\title{
A narrative review of facilitators and barriers to smoking cessation and tobacco-dependence treatment in patients with tuberculosis in low- and middle-income countries
}

\author{
Kamila Zvolska ${ }^{1}$, Alexandra Pankova ${ }^{2,1}$, Iveta Nohavova ${ }^{1,2}$, Rumana Huque ${ }^{3}$, Helen Elsey ${ }^{4}$, Melanie Boeckmann ${ }^{5,4,6}$, Aziz \\ Sheikh ${ }^{7}$, Kamran Siddiqii, Eva Kralikova ${ }^{1,2}$
}

\begin{abstract}
INTRODUCTION Smoking is a substantial cause of premature death in patients with tuberculosis (TB), particularly in low- and middle-income countries (LMICs) with high TB prevalence. The importance of incorporating smoking cessation and tobacco-dependence treatment (TDT) into TB care is highlighted in the most recent TB care guidelines. Our objective is to identify the likely key facilitators of and barriers to smoking cessation for patients with TB in LMICs.

METHODS A systematic search of studies with English-language abstracts published between January 2000 and May 2019 was undertaken in the EMBASE, MEDLINE, EBSCO, ProQuest, Cochrane and Web of Science databases. Data extraction was followed by study-quality assessment and a descriptive and narrative synthesis of findings.

RESULTS Out of 267 potentially eligible articles, 36 satisfied the inclusion criteria. Methodological quality of non-randomized studies was variable; low risk of bias was assessed in most randomized controlled studies. Identified facilitators included brief, repeated interventions, personalized behavioural counselling, offer of pharmacotherapy, smoke-free homes and a reasonable awareness of smoking-associated risks. Barriers included craving for a cigarette, low level of education, unemployment, easy access to tobacco in the hospital setting, lack of knowledge about quit strategies, and limited space and privacy at the clinics. Findings show that the risk of smoking relapse could be reduced through consistent follow-up upon completion of TB therapy and receiving a disease-specific smoking cessation message. CONCLUSIONS Raising awareness of smoking-related health risks in patients with TB and implementing guideline-recommended standardized TDT within national TB programmes could increase smoking cessation rates in this high-risk population.
\end{abstract}

ABBREVIATIONS BSS: behavioural support session, DOTS: directly observed treatment short-course (also known as TB-DOTS), HIC: high-income countries, HW: health workers, LHW: lay health workers, LMICs: low- and middle-income countries, MA: medical assistants, MI: motivational interviewing, NGO: non-governmental organisations, NRT: nicotine replacement therapy, RCS: randomized controlled studies, SCI: smoking cessation intervention, SCIDOTS: directly observed therapy shortcourse plus smoking cessation intervention, SLT: smokeless tobacco, TB: tuberculosis, TDT: tobacco dependence treatment, WHO: World Health Organization.
AFFILIATION

1 Centre for Tobacco-Dependent, Third Department of Medicine, Department of Endocrinology and Metabolism, First Faculty of Medicine, Charles University, Prague, Czech Republic

2 Institute of Hygiene and Epidemiology, First Faculty of Medicine, Charles University, Prague,

Czech Republic

3 Department of Research and Development, ARK Foundation, Dhaka, Bangladesh

4 Department of Health Sciences, University of York, York, United Kingdom 5 Department of Environment and Health, School of Public Health, Bielefeld University, Bielefeld, Germany 6 Institute of General Practice, Addiction Research and Clinical Epidemiology Unit, Medical Faculty, Heinrich-Heine-University, Düsseldorf, Germany

7 Usher Institute, University of Edinburgh, Edinburgh, United Kingdom

\section{CORRESPONDENCE TO}

Kamila Zvolska. Centre for TobaccoDependent, Third Department of Medicine, Department of Endocrinology and Metabolism, First Faculty of Medicine, Charles University, Karlovo namesti 32, 128 08 Prague 2, Czech Republic. E-mail: kamila.zvolska@vfn.cz ORCID ID: https://orcid.org/00000002-5408-0144

KEYWORDS

tuberculosis, developing countries, tobacco use disorder, smoking cessation, barriers and facilitators

Received: 18 May 2020

Revised: 7 June 2020

Accepted: 10 July 2020 


\section{INTRODUCTION}

The 'dual epidemics' of pulmonary tuberculosis (TB) and tobacco smoking are major global public health challenges faced especially by low- and middleincome countries (LMICs) ${ }^{1,2}$. Tobacco smoking increases the risk of pulmonary TB infection, development of pulmonary TB and related mortality, and is closely associated with multi-drug resistant $\mathrm{TB}^{3}$. Smoking is positively associated with poor TB treatment outcomes, especially treatment failures and early deaths ${ }^{4}$.

Abstinence from smoking is essential for patients with TB. TB mortality rates drop substantially after quitting smoking ${ }^{5}$; interestingly, however, Jeyashree et al. ${ }^{6}$ did not find any randomized controlled trials to support the effect of smoking cessation on TB treatment outcomes. Two comprehensive practice and policy guidelines on tobacco cessation interventions within TB programmes were developed by the World Health Organization (WHO) and the International Union Against Tuberculosis and Lung Disease (IUATLD) $)^{1,3}$. These guidelines highlight the importance of incorporating professional tobaccodependence treatment (TDT) into TB care. While only about $4 \%$ of unassisted quit attempts in the general population are successful ${ }^{7}$, simple advice from a clinician to patients with TB who smoke has been shown to increase abstinence rates significantly (by $30 \%$ ) compared to no advice ${ }^{1}$. Although in general populations, behavioural support combined with pharmacotherapy is the most effective strategy in helping people to quit, there is no evidence for the effectiveness of this strategy in TB patients who smoke. While medications are widely recommended, their costs prohibit their use in $\mathrm{LMICs}^{8}$.

A systematic review of the effectiveness of smoking cessation interventions among TB patients was already published, but little is known about the factors that affect smoking cessation and TDT in these patients. Thus, we conducted a narrative literature review with the main aim to identify facilitators and barriers that affect smoking cessation and TDT among people with TB in LMICs.

\section{METHODS}

\section{Search strategy}

A systematic search was conducted by the Institute of Scientific Information of the First Faculty of Medicine,
Charles University in Prague, Czech Republic. The search was carried out in May 2019 and was followed by manual literature searches in the reference lists from the retrieved articles and through MEDLINE database to identify referenced articles and additional articles on smoking cessation in the TB context in LMICs ${ }^{9}$. Records were identified through searches in: 1) Ovid-EMBASE and MEDLINE databases selected, 2) EBSCO databases - Academic Search Complete database selected, 3) ProQuest, 4) Cochrane, and 5) Web of Science databases; and included articles published between January 2000 and May 2019 according to the inclusion and exclusion criteria described below (see the search strategy in the Figure 1 flow diagram). Search terms and combinations thereof included: [facilitators OR barriers OR effectiveness OR success rate OR factors OR outcome(s) OR abstinence] AND [low-income countries OR middle-income countries OR specific countries according to the World Bank] AND [tobacco OR tobacco use cessation OR smoking OR smoking cessation OR treatment] AND [TB OR tuberculosis OR TB programme].

\section{Research question}

What are the facilitators and barriers for people with TB to quit smoking in LMICs?

\section{Inclusion and exclusion criteria}

Inclusion criteria of present review were: Englishlanguage abstract of the article (irrespective of the language used in the main text), study population focused at people with TB in LMICs (according to the World Bank) ${ }^{9}$ who smoke (self-reported or biochemically validated smoking status) and were aged $\geq 15$ years. We excluded studies on only smoking prevention and prevalence, those of not original research, and if no full text was available.

\section{Study selection}

The eligibility of studies was assessed using the inclusion criteria by two investigators (EK, KZ). A third investigator (AP) resolved any discrepancies in the opinions of the two investigators, checked by IN, and comments included from RH, HE, AS and KS.

\section{Data extraction and quality assessment}

Data extraction was conducted by one reviewer 
Figure 1. PRISMA flow diagram illustrating the literature selection process

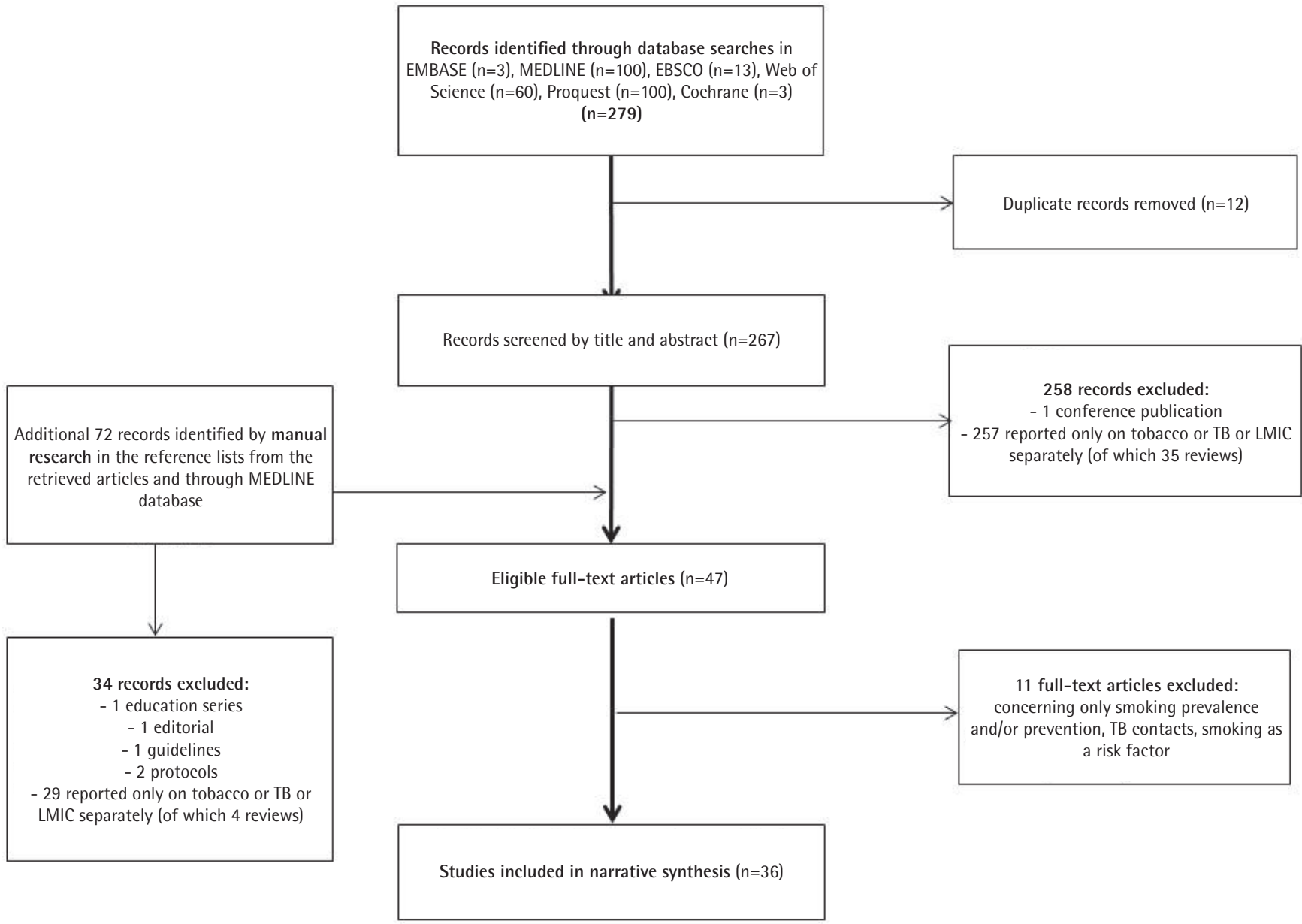

to be subsequently discussed and checked by at least one other reviewer. Extracted data included the following items: author/year, country, study design, sample size, study purpose, findings, limitations, and quality assessment. Quality assessment was performed after data extraction and done independently by two reviewers (KZ, EK). Randomized controlled studies (RCS) were assessed using the Cochrane Risk of Bias tool for intervention studies ${ }^{10}$, non-randomized studies using the Newcastle-Ottawa Scale (NOS) and modified NOS adapted for cross-sectional studies ${ }^{11}$.

\section{Data synthesis and reporting}

We descriptively summarised data and undertook a narrative synthesis of findings. PRISMA was used to inform reporting.

\section{RESULTS}

The initial search generated 267 potentially eligible articles after duplication removal, plus 72 records identified additionally by manual search $(n=339)$ (Figure 1, PRISMA flow diagram) ${ }^{12}$. Only 36 publications were deemed relevant for review after screening abstracts and full texts according to the prespecified inclusion and exclusion criteria. Of those papers excluded, $94.4 \%$ (286/303) reported only on tobacco or TB or LMICs separately, 11 (3.6\%) were excluded for being prevention or prevalence studies, or for assessing smoking as a risk factor, with the remainder $(2 \%)$ not being original research.

\section{Characteristics of eligible studies}

Regarding design, the selected studies were prospective (including randomized controlled and 
non-randomized studies), cross-sectional studies, and qualitative studies. All studies but one (in French) were published in English. Eight of the included studies were $\mathrm{RCS}^{13-20}, 28$ articles reported on non-randomized studies ${ }^{21-48}$. Characteristics of the studies and their main findings are presented in Tables 1 and 2. Only one study recruited patients aged $\geq 15$ years, with the participants of the other studies aged $\geq 18$ years. Studies were conducted mainly in TB clinics, centres or units, health centres registered as diagnostic by TB program or provided DOTS services, respiratory clinics and, less often, in primary healthcare services. One study intervention was provided at home. In addition to smoking of cigarettes followed in all studies, 1 study included also rolled tendu or temburni leaf (bidi) smoking, 2 studies a hookah session, and 7 studies the use of smokeless tobacco. Data extracted from the studies were reviewed to identify possible facilitators of and barriers to smoking cessation or TDT and relapse (Table 3 ). Table 4 shows factors associated with smoking relapse among $\mathrm{TB}$ patients.

\section{Study quality}

The inclusion criteria were met by 8 RCS, two of which were secondary analyses of data obtained from the selected studies (Table 1). Low risk of bias was assessed in 7 of 8 RCS (Table 5). The inclusion criteria were met by 28 non-randomized studies of variable methodological quality (Table 2).

\section{Facilitators of smoking cessation/TDT in patients with TB of LMICs}

Facilitators of smoking cessation/TDT in patients with TB of LMICs are summarized in Table 3.

The most frequently described facilitators that foster smoking cessation/TDT in TB patients were repeated brief interventions (including motivation and brochures $)^{15-17,28,31}$ followed by personalized behavioural counselling incorporated into routine TB services ${ }^{24,35,43,46}$. The SCIDOT project showed that adding smoking cessation intervention (SCI) to conventional DOTS increased biochemically validated 6-month abstinence ${ }^{24}$. RCS assessing behavioural intervention considered it an effective part of treatment increasing the success rate in quitting:

- The study of Louwagie et al. ${ }^{17}$ from South Africa reported higher efficacy of a brief motivational interviewing session (15-20 min) provided by lay healthcare workers (LHW) compared to only receiving standardized smoking cessation messages from a TB nurse and a smoking cessation booklet (control group).

- Smokers who received smoking cessation intervention ( $\mathrm{SCI}$ ) from a TB health visitor trained to deliver the $\mathrm{ABC}$ package $(\mathrm{A}=$ ask, $\mathrm{B}=$ brief advice, $\mathrm{C}=$ cessation support) were more likely to quit smoking compared to those who received existing standard of care in TB case management in India ${ }^{15}$.

- In the study by Kumar et al. ${ }^{16}$, the quit rate in the intervention group (physicians' advice) was higher compared to the control group, but with no significant difference. However, the study evaluated only a 1 -month abstinence period in a relatively small sample.

Three RCS studies confirmed the efficacy of combined interventions (behavioural support plus pharmacotherapy) in achieving longer-term abstinence at six months:

- The ASSIST study compared the success rates in a group treated by behavioural support (30-min consultation to encourage patients to plan smoking cessation 1 week later, and a 10-min session to review progress) combined with 7 weeks of bupropion therapy $(75 \mathrm{mg}$ /day during week 1 , and $150 \mathrm{mg}$ /day thereafter) to behavioural support only and usual care ${ }^{20}$.

- A similarly combined intervention that included behavioural therapy plus medical treatment with bupropion $150 \mathrm{mg}$ /day during week 1, increased to $300 \mathrm{mg} /$ day through week 9 led to success rates of $71.7 \%$ vs $33.9 \%$ for the brief advice group vs $9.8 \%$ for a control group receiving only the short-course, directly-observed treatment (DOTS) regimen $(\mathrm{p}<0.001)^{13}$.

- Biochemically verified quit rates were higher in the intervention arm ( 6 weeks of nicotine gum after which both arms received the same counselling) than in the control arm $(47.8 \% \text { vs } 32.4 \%, \mathrm{p}<0.001)^{19}$. Two studies showed efficacy of repeated tobacco use intervention follow-up at a minimum of 6 months after end of TB treatment ${ }^{30,43}$.

In a secondary analysis of the ASSIST study ${ }^{20}$, Elsey et al. ${ }^{14}$ concluded that patients diagnosed with TB were more likely to be abstinent than those diagnosed with other respiratory conditions. 
Review Paper

Table 1. Summary of included randomized controlled studies concerning smoking cessation/TDT in patients with TB of LMICs (N=8)

\begin{tabular}{|c|c|c|c|c|c|c|}
\hline $\begin{array}{l}\text { Author, } \\
\text { year }\end{array}$ & Location & Study design & $\begin{array}{l}\text { Sample size/ age/sex/type of } \\
\text { sample }\end{array}$ & Study purpose & Findings & Limitations \\
\hline $\begin{array}{l}\text { Aryanpur } \\
\text { et al. }{ }^{13} \\
(2016)\end{array}$ & Iran & $\begin{array}{l}\text { Randomized } \\
\text { controlled study }\end{array}$ & $\begin{array}{l}n=183 \text { newly-diagnosed } \\
\text { (confirmed) patients who } \\
\text { currently smoke with pulmonary } \\
\text { TB, aged }>18 \text { years. }\end{array}$ & Success rate at 6 months. & $\begin{array}{l}\text { Combined intervention including individualized counselling sessions of } \\
\text { quitting (behavioural therapy) plus medical treatment with slow- release } \\
\text { bupropion can lead to a significant increase }(71.7 \%) \text { in the rate of } \\
\text { continuous smoking cessation at the end of sixth months. }\end{array}$ & $\begin{array}{l}\text { The outcome of smoking } \\
\text { cessation was measured } \\
\text { until the end of TB } \\
\text { treatment. }\end{array}$ \\
\hline
\end{tabular}

Setting: health centres

implementing the Directly

Observed Treatment Short Course

(DOTS) strategy.

\begin{tabular}{|c|c|c|c|c|c|}
\hline $\begin{array}{l}\text { Elsey et } \\
\text { al. } .^{14} \\
(2015)\end{array}$ & Pakistan & $\begin{array}{l}\text { Cluster } \\
\text { randomized } \\
\text { controlled study, a } \\
\text { secondary analysis } \\
\text { (data from the } \\
\text { ASSIST trial) }\end{array}$ & $\begin{array}{l}n=1573 \text { patients aged }>18 \text { years } \\
\text { who were regular smokers of } \\
\text { more than } 1 \text { cigarette or hookah } \\
\text { session a day. } \\
\text { Setting: health centres registered } \\
\text { as diagnostic centres by the TB } \\
\text { program. }\end{array}$ & $\begin{array}{l}\text { To identify predictors of } \\
\text { continuous and short-term } \\
\text { abstinence, and continued } \\
\text { smoking in patients suspected } \\
\text { of TB. }\end{array}$ & $\begin{array}{l}\text { A confirmed TB diagnosis was a significant predictor of continuous } \\
\text { abstinence at } 25 \text { weeks, gender does not predict cessation, socio-familial } \\
\text { context particularly at work may undermine smokers' ability to achieve } \\
\text { continuous abstinence, having a child at home was not a significant } \\
\text { predictor of abstinence. }\end{array}$ \\
\hline $\begin{array}{l}\text { Goel et } \\
\text { al. } .^{15} \\
(2017)\end{array}$ & India & $\begin{array}{l}\text { Cluster } \\
\text { randomized } \\
\text { controlled study }\end{array}$ & $\begin{array}{l}\mathrm{n}=152 \text { sputum smear-positive } \\
\text { pulmonary TB patients, aged } \\
\geq 15 \text { years, who were current and } \\
\text { occasional smokers; } 96.7 \% \text { men, } \\
\text { aged } 30-44 \text { years. } \\
\text { Setting: TB units }\end{array}$ & $\begin{array}{l}\text { To assess treatment success (= } \\
\text { the sum of cured, smear- or } \\
\text { culture-negative patients in } \\
\text { the last month of treatment) } \\
\text { and to assess smoking } \\
\text { cessation rates (patient had } \\
\text { not smoked at all in the last } 2 \\
\text { weeks). }\end{array}$ & $\begin{array}{l}\text { Difference in TB treatment outcome was found to be insignificant between } \\
\text { intervention (ABC intervention from TB health visitor) and control arm. } \\
\text { Treatment success was higher among quitters }(74.7 \%) \text { compared to smokers } \\
(25.2 \%) \text {, the difference was found to be significant (IRR=1.31; } 95 \% \mathrm{Cl} \text { : } \\
1.30-1.32 ; \mathrm{p} \leq 0.0001) \text {. At the end of treatment, } 57(80.2 \%) \text { patients in the } \\
\text { intervention arm had quit smoking against } 42(57.5 \%) \text { in the control arm. } \\
\text { After adjusting for confounders, the relative risk of quitting during follow- } \\
\text { up was significantly higher in the intervention arm compared to the control } \\
\text { arm for both PP analysis (adjusted IRR=1.56; } 95 \% \mathrm{Cl}: 1.24-1.93 ; \mathrm{p}<0.0001) \text {. }\end{array}$ \\
\hline $\begin{array}{l}\text { Kumar et } \\
\text { al. }^{16} \\
(2017)\end{array}$ & India & $\begin{array}{l}\text { Randomized } \\
\text { clinical study }\end{array}$ & $\begin{array}{l}\mathrm{n}=73 \text { patients aged }>18 \text { years, } \\
\text { with TB and with a history of } \\
\text { current smoking ( } 80 \text { with HIV } \\
\text { infection and } 80 \text { with TB). } \\
\text { Setting: clinic }\end{array}$ & $\begin{array}{l}\text { To determine the efficacy of } \\
\text { physicians' advice in addition } \\
\text { to standard counselling } \\
\text { compared with standard } \\
\text { counselling alone in quitting } \\
\text { smoking. }\end{array}$ & $\begin{array}{l}\text { Among the patients with TB receiving physician's advice using a modified } \\
\text { version of the } 5 \text { As strategy for smoking cessation plus a brochure containing } \\
\text { smoking cessation information with standard counselling, } 44.4 \%(16 / 36) \\
\text { quit smoking, while } 40.5 \% \text { (15/37) quit smoking with counselling from the } \\
\text { counsellors alone plus a brochure containing smoking cessation information } \\
(p=0.735) \text {. }\end{array}$ \\
\hline
\end{tabular}

see Siddiqi et al. ${ }^{20}(2013)$

Insignificant difference in TB treatment outcome could

be due to the fact that for an intervention to bring positive treatment outcome, the total time spent for each session should be relatively more than it was in the study.

Only a 1-month abstinence period was assessed.

counselling alone in quitting $(p=0.735)$ 


\section{Table 1. Continued}

\begin{tabular}{|c|c|c|c|c|c|c|}
\hline $\begin{array}{l}\text { Author, } \\
\text { year }\end{array}$ & Location & Study design & $\begin{array}{c}\text { Sample size/ age/sex/type of } \\
\text { sample }\end{array}$ & Study purpose & Findings & Limitations \\
\hline $\begin{array}{l}\text { Louwagie } \\
\text { et al. }{ }^{17} \\
(2014)\end{array}$ & $\begin{array}{l}\text { South } \\
\text { Africa }\end{array}$ & $\begin{array}{l}\text { Randomized } \\
\text { controlled } \\
\text { intervention study }\end{array}$ & $\begin{array}{l}\mathrm{n}=409 \text { newly diagnosed adult } \\
\text { patients with TB identified as } \\
\text { current smokers. } \\
\text { Setting: primary care public } \\
\text { facilities }\end{array}$ & $\begin{array}{l}\text { To determine the efficacy of } \\
\text { brief motivational interviewing } \\
\text { by lay health workers (LHW) } \\
\text { in assisting TB patients with } \\
\text { tobacco cessation in a setting } \\
\text { with high HIV-TB coinfection } \\
\text { rates. }\end{array}$ & $\begin{array}{l}\text { Motivational interviewing (MI) by lay counsellors to promote smoking } \\
\text { cessation in TB patients approximately doubled sustained biochemically } \\
\text { verified smoking abstinence for at least } 6 \text { months compared with brief } \\
\text { advice alone [24/83 (28.9\%) vs } 11 / 83(13.3 \%)] \text {. }\end{array}$ & $\begin{array}{l}\text { MI was offered in only } \\
\text { a single brief session by } \\
\text { LHCWs. LHCWs delivered } \\
\text { MI without monitoring } \\
\text { by video-taping. Follow- } \\
\text { up measurement was not } \\
\text { blinded. Pharmacotherapy } \\
\text { was not offered to } \\
\text { smokers because of local } \\
\text { unavailability. Potential } \\
\text { over-reporting of self- } \\
\text { reported quit rates. }\end{array}$ \\
\hline $\begin{array}{l}\text { Louwagie } \\
\text { \&t Ayo- } \\
\text { Yusuf }{ }^{18} \\
\text { (2015) }\end{array}$ & $\begin{array}{l}\text { South } \\
\text { Africa }\end{array}$ & $\begin{array}{l}\text { A secondary } \\
\text { analysis of } \\
\text { results from } \\
\text { the randomized } \\
\text { controlled trial } \\
\text { (Louwagie et } \text { al. }^{17} \text { ) }\end{array}$ & $\begin{array}{l}409 \text { randomized patients, current } \\
\text { smokers, being } \geq 18 \text { years, being } \\
\text { on TB treatment for less than one } \\
\text { month. } \\
\text { Setting: primary care public } \\
\text { facilities }\end{array}$ & $\begin{array}{l}\text { To identify independent } \\
\text { predictors of smoking } \\
\text { cessation after adjusting for } \\
\text { the intervention effect. }\end{array}$ & $\begin{array}{l}\text { Smokers with high nicotine dependence were less likely to quit than those } \\
\text { with low nicotine dependence during 1-month follow-up, but this effect } \\
\text { was not sustained beyond this point in time. In multivariate analysis of the } \\
\text { predictors of 7-day point prevalence abstinence during 1-month follow-up, } \\
\text { motivational interviewing intervention was significantly effective only for } \\
\text { those with nicotine dependence (OR=3.01;95\% Cl: 1.74-5.21). }\end{array}$ & $\begin{array}{l}\text { Potentially too small sample } \\
\text { size to detect certain } \\
\text { associations; self-reported } \\
\text { smoking abstinence. }\end{array}$ \\
\hline $\begin{array}{l}\text { Sharma et } \\
\text { al. }^{19} \\
(2018)\end{array}$ & India & $\begin{array}{l}\text { Open-label, } \\
\text { randomized } \\
\text { controlled study }\end{array}$ & $\begin{array}{l}\text { Eight hundred adult patients } \\
\text { enrolled ( }>18 \text { years) with newly } \\
\text { diagnosed sputum-positive } \\
\text { pulmonary TB with self-reported } \\
\text { history of current cigarette/ } \\
\text { rolled tendu or temburni leaf } \\
\text { (bidi) smoking (more than } 10 \text { per } \\
\text { day, every day for at least two } \\
\text { months). } \\
\text { Setting: DOTS centres }\end{array}$ & $\begin{array}{l}\text { Primary outcome = a change } \\
\text { in the TB score at } 24 \text { weeks } \\
\text { and sputum culture conversion } \\
\text { at week eight. Secondary } \\
\text { outcomes = time to sputum } \\
\text { smear conversion, weight } \\
\text { gain at } 24 \text { weeks, number } \\
\text { of patients who have quit } \\
\text { smoking at } 24 \text { weeks, and } \\
\text { mortality at } 24 \text { weeks. }\end{array}$ & $\begin{array}{l}\text { Although intervention of nicotine replacement treatment (NRT) (nicotine } \\
\text { gum } 2 \mathrm{mg} \text { for smokers up to } 25 \text { bidis/cigarettes/day or } 4 \mathrm{mg} \text { for those } \\
\text { smoking more for } 6 \text { weeks) combined with counselling achieved higher quit } \\
\text { rates ( } 47.8 \% \text { versus } 32.4 \% \text { for control group) and a greater reduction in TB } \\
\text { score was seen in intervention arm, TB score did not meaningfully change at } \\
8 \text { and } 24 \text { weeks. Subsequent to treatment completion, most patients in both } \\
\text { arms reported re-initiation of tobacco smoking ( } 80.6 \% \text { vs } 79.7 \% \text { ). }\end{array}$ & $\begin{array}{l}\text { The trial did not have a 'drug } \\
\text { treatment only' arm without } \\
\text { counselling. Also, the results } \\
\text { of the study are ascribable } \\
\text { to predominantly a single } \\
\text { centre. The absent sputum } \\
\text { production in a significant } \\
\text { proportion of patients led } \\
\text { to high loss to follow-up } \\
\text { of the culture reports. } \\
\text { Socioeconomic factors were } \\
\text { not noted during the study. }\end{array}$ \\
\hline
\end{tabular}


Review Paper

Table 1. Continued

\begin{tabular}{|c|c|c|c|c|c|c|}
\hline $\begin{array}{l}\text { Author, } \\
\text { year }\end{array}$ & Location & Study design & $\begin{array}{c}\text { Sample size/ age/sex/type of } \\
\text { sample }\end{array}$ & Study purpose & Findings & Limitations \\
\hline $\begin{array}{l}\text { Siddiqi et } \\
\text { al. }^{20} \\
(2013)\end{array}$ & Pakistan & $\begin{array}{l}\text { Cluster } \\
\text { randomized } \\
\text { controlled study } \\
\text { (the ASSIST trial) }\end{array}$ & $\begin{array}{l}n=1955 \text { participants aged }>18 \\
\text { years who were regular smokers of } \\
\text { more than } 1 \text { cigarette or hookah } \\
\text { session a day with suspected } \\
\text { pulmonary TB. } \\
\text { Setting: health centres registered } \\
\text { as diagnostic centres by the TB } \\
\text { program }\end{array}$ & $\begin{array}{l}\text { Continuous CO-measured } \\
\text { smoking abstinence at follow- } \\
\text { up at } 1 \text { month and } 6 \text { months. }\end{array}$ & $\begin{array}{l}\text { Behavioural support session (BBS) alone or with bupropion (BBS+) was } \\
\text { effective in achieving continuous abstinence at } 6 \text { months for } B S S+(R R=8.2 \text {; } \\
95 \% \mathrm{Cl}: 3.7-18.2 \text { ), and for BBS alone ( } R R=7.4 ; 95 \% \mathrm{Cl}: 3.4-16.4) \text {. }\end{array}$ & $\begin{array}{l}\text { Imbalances in the urban } \\
\text { and rural proportions and } \\
\text { smoking habits among } \\
\text { treatment groups, inability } \\
\text { to confirm adherence to } \\
\text { bupropion treatment, and } \\
\text { inability to validate longer- } \\
\text { term abstinence or the } \\
\text { effect of smoking cessation } \\
\text { on TB outcomes. }\end{array}$ \\
\hline
\end{tabular}


Review Paper

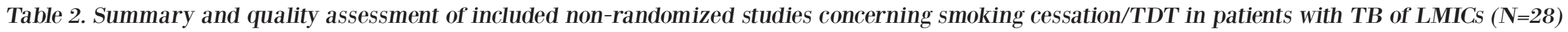

\begin{tabular}{|c|c|c|c|c|c|c|c|c|c|}
\hline Author, year & Country & Study design & $\begin{array}{l}\text { Sample size/age/ } \\
\text { sex/type of sample }\end{array}$ & Study purpose & Findings & Limitations & Selection* & Comparability* & Outcome* \\
\hline $\begin{array}{l}\text { Amara et al. }{ }^{21} \\
(2008)\end{array}$ & Morocco & $\begin{array}{l}\text { Comprehensive } \\
\text { cross-sectional } \\
\text { telephone } \\
\text { survey }\end{array}$ & $\begin{array}{l}75 \text { respiratory } \\
\text { physicians working } \\
\text { in TB diagnosis and } \\
\text { monitoring centres; } \\
10.7 \% \text { smokers } \\
(8 / 75), 58.7 \% \text { men. }\end{array}$ & $\begin{array}{l}\text { To evaluate attitudes and } \\
\text { knowledge of Moroccan } \\
\text { respiratory physicians towards } \\
\text { smoking in the management } \\
\text { of patients with TB and the } \\
\text { feasibility of integrating smoking } \\
\text { interventions into the national } \\
\text { TB program. } \\
\text { Of these, 84\% still reported } \\
\text { smoking status in patients' } \\
\text { medical records. }\end{array}$ & $\begin{array}{l}66.7 \% \text { of those interviewed by } \\
\text { phone were certain that smoking } \\
\text { increases the incidence of TB, } \\
96 \% \text { believed that smoking } \\
\text { would worsen the disease. More } \\
\text { than } 84 \% \text { of the physicians } \\
\text { inquired their patients about } \\
\text { their smoking habits. Only } 5.3 \% \\
\text { believed they were well trained } \\
\text { to help smokers to stop. }\end{array}$ & Not reported & *** & & * \\
\hline $\begin{array}{l}\text { Aryanpur et } \\
\text { al.22 } \\
(2016)\end{array}$ & Iran & $\begin{array}{l}\text { Cross- } \\
\text { sectional study }\end{array}$ & $\begin{array}{l}\text { Newly-diagnosed } \\
\text { PTB patients aged } \\
\geq 18 \text { years; self- } \\
\text { reported smoking } \\
\text { status; } 248(22 \%) \\
\text { patients were current } \\
\text { smokers including } \\
228(20.2 \%) \text { daily } \\
\text { smokers and } 20 \\
(1.8 \%) \text { occasional } \\
\text { smokers. } \\
\text { Setting: health }\end{array}$ & $\begin{array}{l}\text { To determine the intention to } \\
\text { quit and its associated factors } \\
\text { among smokers newly diagnosed } \\
\text { with PTB. }\end{array}$ & $\begin{array}{l}\text { When diagnosed with TB, } 59 \\
\text { smoker patients ( } 23.8 \%) \text { quit } \\
\text { smoking. After PTB diagnosis, } \\
99 \text { patients }(52.4 \%) \text { had the } \\
\text { intention to quit in the next } \\
\text { month. Living in urban areas, } \\
\text { office jobs, being single and } \\
\text { a one unit increase in the } \\
\text { motivation scale significantly } \\
\text { increased the intention to quit } \\
\text { smoking. }\end{array}$ & $\begin{array}{l}\text { Cross-sectional nature of this } \\
\text { study does not allow evaluation } \\
\text { of the causal relationship } \\
\text { between factors and smoking } \\
\text { cessation, and its prognostic } \\
\text { factors. Thus, further prospective } \\
\text { studies are required. Meanwhile, } \\
\text { as this study was conducted on } \\
\text { patients with newly diagnosed } \\
\text { PTB, its results cannot be } \\
\text { generalized to all TB patients. }\end{array}$ & ** & & $* *$ \\
\hline
\end{tabular}


Review Paper

Table 2. Continued

\begin{tabular}{|c|c|c|c|c|c|c|c|c|c|}
\hline Author, year & Country & Study design & $\begin{array}{l}\text { Sample size/age/ } \\
\text { sex/type of sample }\end{array}$ & Study purpose & Findings & Limitations & Selection* & Comparability* & Outcome* \\
\hline $\begin{array}{l}\text { Awaisu et al. }{ }^{23} \\
(2010)\end{array}$ & Malaysia & $\begin{array}{l}\text { Cross- } \\
\text { sectional study }\end{array}$ & $\begin{array}{l}\mathrm{n}=817 \text { newly } \\
\text { diagnosed TB } \\
\text { patients, } 40.3 \% \\
\text { were smokers, } \\
13.9 \% \text { ex-smokers; } \\
120 \text { enrolled in the } \\
\text { SCIDOTS project, } \\
\text { 98.7\% were males. } \\
\text { Setting: TB clinics }\end{array}$ & $\begin{array}{l}\text { To determine the prevalence of } \\
\text { smoking among newly diagnosed } \\
\text { TB patients and to evaluate } \\
\text { the tobacco use knowledge } \\
\text { and attitudes of those who are } \\
\text { smokers in this population using } \\
\text { a 58-item questionnaire. }\end{array}$ & $\begin{array}{l}\text { Patients who were in the } \\
\text { stage of contemplation/pre- } \\
\text { contemplation had significantly } \\
\text { less knowledge than those in } \\
\text { the preparation stage of change } \\
\text { (3.73 vs 5.38; } p=0.004) .65 .1 \% \text { of } \\
\text { patients believed that smoking } \\
\text { is fun and } 61.3 \% \text { that it calms } \\
\text { nerves. } 70.1 \% \text { of respondents } \\
\text { also agreed or strongly agreed } \\
\text { that smoking makes them relieve } \\
\text { all life stresses. However, } 87.5 \% \\
\text { of patients agreed or strongly } \\
\text { agreed that: smoking is a waste } \\
\text { of money, } 91.3 \% \text { that tobacco } \\
\text { use is very dangerous to health; } \\
\text { and } 81.3 \% \text { that smokers are } \\
\text { more likely to die from heart } \\
\text { disease compared with non- } \\
\text { smokers. }\end{array}$ & $\begin{array}{l}\text { The rates in study might have } \\
\text { been grossly underestimated } \\
\text { due to the unknown smoking } \\
\text { status of a reasonable proportion } \\
\text { of the newly diagnosed TB } \\
\text { patients who might as well be } \\
\text { tobacco smokers. A trend of } \\
\text { underestimation when smoking } \\
\text { prevalence is based on self- } \\
\text { reports. }\end{array}$ & ** & & ** \\
\hline
\end{tabular}


Review Paper

Table 2. Continued

\begin{tabular}{|c|c|c|c|c|c|c|c|c|c|}
\hline Author, year & Country & Study design & $\begin{array}{l}\text { Sample size/age/ } \\
\text { sex/type of sample }\end{array}$ & Study purpose & Findings & Limitations & Selection* & Comparability* & Outcome* \\
\hline $\begin{array}{l}\text { Awaisu et al. }{ }^{24} \\
\text { (2011) }\end{array}$ & Malaysia & $\begin{array}{l}\text { Prospective } \\
\text { non- } \\
\text { randomized } \\
\text { controlled } \\
\text { intervention } \\
\text { (the SCIDOT } \\
\text { project) }\end{array}$ & $\begin{array}{l}n=80 \text { current } \\
\text { smokers at the time } \\
\text { of TB diagnosis; } 40 \\
\text { patients motivated } \\
\text { to quit smoking (in } \\
\text { preparation stage) } \\
\text { received SCl in } \\
\text { addition to DOTS (the } \\
\text { intervention group } \\
\text { and } 46 \text { unmotivated } \\
\text { patients (in pre- } \\
\text { contemplation and } \\
\text { contemplation } \\
\text { stages) received } \\
\text { conventional DOTS } \\
\text { regimen (the usual } \\
\text { care group). SCl } \\
\text { = eleven sessions } \\
\text { of individualized } \\
\text { cognitive behavioural } \\
\text { therapy with (60\%) } \\
\text { or without (40\%) } \\
\text { nicotine replacement } \\
\text { therapy (nicotine } \\
\text { gum } 2 \text { mg and } 4 \text { mg, } \\
\text { nicotine transdermal } \\
\text { patch, and nicotine } \\
\text { inhaler). } \\
\text { Setting: respiratory } \\
\text { clinics }\end{array}$ & $\begin{array}{l}\text { To evaluate the impact of adding } \\
\text { smoking cessation intervention } \\
\text { (SCI) to conventional DOTS for } \\
\text { TB on tobacco abstinence rates } \\
\text { and TB treatment outcomes. }\end{array}$ & $\begin{array}{l}\text { Subjects in the DOTS group were } \\
\text { more dependent on nicotine } \\
\text { than those in the SCIDOTS group } \\
\text { (FTND, } 5.43 \pm 1.96 \text { vs } 4.32 \pm \\
2.26 ; t=-2.439 ; p=0.017) \text {. At } \\
\text { the end of } 6 \text {-month follow-up, } \\
\text { the one-month self-reported } \\
\text { continuous abstinence rate, } \\
\text { confirmed biochemically by both } \\
\mathrm{C} 0 \text { and saliva cotinine tests, } \\
\text { was nearly } 78 \%(31 / 40) \text { in the } \\
\text { intervention group versus } 9 \% \\
\text { (4/46) in the usual care group } \\
\text { (Pearson } \times 2=41.97 ; d f=1 ; N=86 ; \\
p<0.001) .\end{array}$ & $\begin{array}{l}\text { The study compared persons } \\
\text { motivated to quit smoking in an } \\
\text { intervention group with those } \\
\text { contemplating quitting smoking } \\
\text { in a control group; therefore, the } \\
\text { observed difference in smoking } \\
\text { cessation between the groups } \\
\text { would likely not have been so } \\
\text { great. }\end{array}$ & **** & * & ** \\
\hline
\end{tabular}


Review Paper

Table 2. Continued

\begin{tabular}{|c|c|c|c|c|c|c|c|c|c|}
\hline Author, year & Country & Study design & $\begin{array}{l}\text { Sample size/age/ } \\
\text { sex/type of sample }\end{array}$ & Study purpose & Findings & Limitations & Selection* & Comparability* & Outcome* \\
\hline $\begin{array}{l}\text { Bam et al. }{ }^{25} \\
(2015)\end{array}$ & Indonesia & Cohort study & $\begin{array}{l}\mathrm{n}=750 \text { new smear- } \\
\text { positive TB patients, } \\
82.3 \% \text { male, } 77.6 \% \\
\text { current smokers. } \\
\text { Of the } 80 \text { healthcare } \\
\text { facilities, } 52 \text { (65 \%) } \\
\text { were tobacco-free } \\
\text { in March 2011, the } \\
\text { number of which } \\
\text { increased to } 80 \\
\text { (100\%) by December } \\
2012 . \text { Smoking was } \\
\text { not permitted in any } \\
\text { buildings, grounds or } \\
\text { carparks. Cigarettes } \\
\text { were not sold, and } \\
\text { tobacco advertising, } \\
\text { promotion and } \\
\text { sponsorship were } \\
\text { not permitted on the } \\
\text { premises. } \\
\text { Setting: health } \\
\text { centres that provided } \\
\text { DOTS services }\end{array}$ & $\begin{array}{l}\text { To assess the implementation } \\
\text { and effectiveness of the } A B C \\
\text { smoking cessation approach } \\
\text { for TB patients and the } \\
\text { establishment of smoke-free } \\
\text { environments in healthcare } \\
\text { facilities and TB patients' homes } \\
\text { in Indonesia. }\end{array}$ & $\begin{array}{l}\text { The point prevalence of the } \\
\text { quit rate was } 66.8 \% \text { (389/582) } \\
\text { at month } 6 \text {. Predictors } \\
\text { independently associated with } \\
\text { quitting were the time from } \\
\text { waking to the first cigarette }>30 \\
\text { min, having a smoke-free home } \\
\text { and the display of 'no smoking' } \\
\text { signage at home at month } 6 \text {. } \\
\text { The ABC smoking cessation } \\
\text { intervention was effective for: } \\
\text { i) creating } 100 \% \text { tobacco-free } \\
\text { health services, ii) promoting } \\
\text { quitting smoking (66.8\%), and } \\
\text { iii) establishing smoke-free } \\
\text { environments at home }(86.1 \%) \text {. }\end{array}$ & $\begin{array}{l}\text { Self-reporting of smoking status } \\
\text { although the status of the } \\
\text { patients' smoking and of their } \\
\text { smoke-free home were validated } \\
\text { with a family member at month } \\
\text { 6. Issues of time constraints and } \\
\text { high workload were raised at the } \\
\text { initial training by the healthcare } \\
\text { staff before the intervention; } \\
\text { however, healthcare workers } \\
\text { reported neither high workloads } \\
\text { nor time constraints during the } \\
\text { review meeting at months } 2,5 \text {, } \\
\text { and } 6 \text {. }\end{array}$ & *** & * & $* * *$ \\
\hline
\end{tabular}


Table 2. Continued

\begin{tabular}{|c|c|c|c|c|c|c|c|c|c|}
\hline Author, year & Country & Study design & $\begin{array}{l}\text { Sample size/age/ } \\
\text { sex/type of sample }\end{array}$ & Study purpose & Findings & Limitations & Selection* & Comparability* & Outcome* \\
\hline $\begin{array}{l}\text { Boeckmann et } \\
\text { al. }^{26} \\
(2019)\end{array}$ & $\begin{array}{l}\text { Bangladesh } \\
\text { and } \\
\text { Pakistan }\end{array}$ & $\begin{array}{l}\text { Qualitative } \\
\text { study }\end{array}$ & $\begin{array}{l}\mathrm{n}=6 \text { healthcare } \\
\text { workers in Pakistan } \\
\text { and } 2 \text { in Bangladesh } \\
\text { ( } 5 \text { men), ranging in } \\
\text { age from } 23 \text { to } 60 \\
\text { years; } n=35 \text { patients } \\
\text { ( } 34 \text { males), age } \\
\text { ranging from } 18 \text { to } \\
60 \text { years } \\
\text { Setting: clinics }\end{array}$ & $\begin{array}{l}\text { Findings of a multi-country } \\
\text { qualitative process evaluation } \\
\text { assessing barriers to and } \\
\text { facilitators of implementation } \\
\text { of smoking cessation behaviour } \\
\text { support in TB clinics in } \\
\text { Bangladesh and Pakistan. }\end{array}$ & $\begin{array}{l}\text { All patients report willingness } \\
\text { to quit smoking and recent } \\
\text { quit attempts. Individuals' main } \\
\text { motivations to quit include their } \\
\text { health and the need to provide } \\
\text { financially for their family. } \\
\text { Behavioural regulation such as } \\
\text { avoiding exposure to cigarettes } \\
\text { and social influences from } \\
\text { friends, family and colleagues } \\
\text { are the main themes of the } \\
\text { interviews. Most male patients } \\
\text { do not feel shy admitting to } \\
\text { smoking, for the sole female } \\
\text { patient interviewee, stigma was } \\
\text { an issue. Health workers report } \\
\text { structural characteristics such as } \\
\text { high workload and limited time } \\
\text { per patient as primary barriers to } \\
\text { offering behavioural support. }\end{array}$ & Sample size, gender bias & $* * *$ & & $* * *$ \\
\hline $\begin{array}{l}\text { Brunet et al. }{ }^{27} \\
\text { (2011) }\end{array}$ & $\begin{array}{l}\text { South } \\
\text { Africa }\end{array}$ & $\begin{array}{l}\text { Cross- } \\
\text { sectional study }\end{array}$ & $\begin{array}{l}\mathrm{n}=424 \text { patients with } \\
\text { suspected TB; mean } \\
\text { age } 39.5 \text { (18-82) } \\
\text { years, } 67 \% \text { male, } \\
71 \% \text { black African, } \\
\text { 28\% HIV infected, } \\
36 \% \text { reported having } \\
\text { previously suffered } \\
\text { from TB, 65\% current } \\
\text { smokers and 17\% } \\
\text { had previously quit } \\
\text { smoking. } \\
\text { Setting: clinics }\end{array}$ & $\begin{array}{l}\text { 1) To estimate the prevalence of } \\
\text { tobacco smoking in patients with } \\
\text { suspected TB; and 2) to measure } \\
\text { the sensitivity and specificity } \\
\text { of their self-reported smoking } \\
\text { status using plasma cotinine as } \\
\text { the reference standard. }\end{array}$ & $\begin{array}{l}\text { The prevalence of current } \\
\text { smoking was estimated at 54\% } \\
\text { (95\% Cl: } 49-58 \% \text { ) by plasma } \\
\text { cotinine and } 57 \% \text { ( } 95 \% \mathrm{Cl} \text { : } \\
52-61 \% \text { ) by self-report. The } \\
\text { sensitivity and specificity of self- } \\
\text { reported smoking was } 89 \% \text { (95\% } \\
\mathrm{Cl}: 84-93 \%) \text { and } 81 \% \text { (95\% } \mathrm{Cl} \text { : } \\
75-86 \%), \text { respectively, using } \\
\text { plasma cotinine as a reference } \\
\text { standard. }\end{array}$ & $\begin{array}{l}\text { Potential mis-classification of } \\
\text { exposure due to self-report. The } \\
\text { use of cotinine concentration } \\
\text { has its own limitations, including } \\
\text { the detection of tobacco chewers } \\
\text { and patients using NRT, and } \\
\text { failure to detect those who had } \\
\text { not smoked for }>48 \mathrm{~h} \text {. }\end{array}$ & $* * *$ & & $* * *$ \\
\hline
\end{tabular}


Review Paper

Table 2. Continued

\begin{tabular}{|c|c|c|c|c|c|c|c|c|c|}
\hline Author, year & Country & Study design & $\begin{array}{l}\text { Sample size/age/ } \\
\text { sex/type of sample }\end{array}$ & Study purpose & Findings & Limitations & Selection* & Comparability* & Outcome* \\
\hline $\begin{array}{l}\text { Campbell et } \\
\text { al. } .^{28} \\
(2014)\end{array}$ & Nepal & $\begin{array}{l}\text { Prospective } \\
\text { controlled } \\
\text { intervention } \\
\text { study }\end{array}$ & $\begin{array}{l}\mathrm{n}=246 \text { cigarette } \\
\text { smokers with smear- } \\
\text { positive pulmonary } \\
\text { TB, aged }>16 \text { years. } \\
\text { Setting: TB centre }\end{array}$ & $\begin{array}{l}\text { Continuous abstinence for more } \\
\text { than } 6 \text { months. }\end{array}$ & $\begin{array}{l}\text { Brief simple (= advice given over } \\
\text { approximately } 10 \text { min at the } \\
\text { beginning of TB treatment by } \\
\text { a staff member, repeated at } 2 \\
\text { and } 5 \text { months into TB treatment) } \\
\text { resulted in a significant number } \\
\text { (39\%) quitting the habit } \\
\text { for } 6 \text { months (CO-validated } \\
\text { abstinence) vs } 0 \% \text { in a control } \\
\text { group without gender difference. }\end{array}$ & $\begin{array}{l}\text { Allocation to intervention or } \\
\text { controls was not randomized. A } \\
\text { further weakness was the delay } \\
\text { of just over } 2 \text { years between the } \\
\text { original training and start of } \\
\text { enrollment, which arose mainly } \\
\text { as a result of administrative } \\
\text { problems. }\end{array}$ & ** & * & $* * *$ \\
\hline $\begin{array}{l}\text { Deepak et al. } .^{29} \\
(2012)\end{array}$ & India & $\begin{array}{l}\text { Community- } \\
\text { based, cross- } \\
\text { sectional study }\end{array}$ & $\begin{array}{l}\mathrm{n}=202 \text { former } \\
\text { patients with TB who } \\
\text { had completed TB } \\
\text { treatment at least } \\
6 \text { months before } \\
\text { the interview; mean } \\
\text { age } 48 \text { years; } 52 \% \\
\text { (106/202) of users of } \\
\text { any form of tobacco, } \\
33 \text { smokers, } 60 \\
\text { smokeless tobacco } \\
\text { (SLT) users, } 13 \text { both } \\
\text { forms. } \\
\text { Setting: TB units }\end{array}$ & $\begin{array}{l}\text { Semi-structured pre-tested } \\
\text { interview schedule; abstinence, } \\
\text { persistence and relapse rates at } \\
\text { eight time-points in relation to } \\
\text { diagnosis of TB and treatment } \\
\text { completion were analyzed } \\
\text { separately for SLT use and } \\
\text { smoking. }\end{array}$ & $\begin{array}{l}\text { The relapse rate of SLT use } \\
\text { was much higher than that of } \\
\text { smoking because most tobacco } \\
\text { messages provided by doctors } \\
\text { to patients were general in } \\
\text { nature and focused on smoking. } \\
\text { More tobacco and TB-specific } \\
\text { cessation messages need to be } \\
\text { given to these patients. }\end{array}$ & $\begin{array}{l}\text { Self-reported tobacco use. The } \\
\text { findings of the study are not } \\
\text { generalizable to all patients } \\
\text { with TB since only patients who } \\
\text { accessed TB units and completed } \\
\text { treatment were studied. }\end{array}$ & $* * *$ & & ** \\
\hline
\end{tabular}


Review Paper

Table 2. Continued

\begin{tabular}{|c|c|c|c|c|c|c|c|c|c|}
\hline Author, year & Country & Study design & $\begin{array}{l}\text { Sample size/age/ } \\
\text { sex/type of sample }\end{array}$ & Study purpose & Findings & Limitations & Selection* & Comparability* & Outcome* \\
\hline $\begin{array}{l}\text { El Sony et al. }{ }^{30} \\
(2007)\end{array}$ & Sudan & $\begin{array}{l}\text { Feasibility } \\
\text { study }\end{array}$ & $\begin{array}{l}48 \text { medical assistants } \\
\text { (MA), all presented } \\
\text { during the study; } \\
\mathrm{n}=513 \text { previously } \\
\text { untreated male } \\
\text { patients (new cases) } \\
\text { who were enrolled } \\
\text { in treatment for } \\
\text { pulmonary TB were } \\
\text { recruited (81\% of } \\
\text { current smokers in } \\
\text { the intervention } \\
\text { group vs } 36 \% \text { in the } \\
\text { control group). } \\
\text { Setting: primary } \\
\text { and respiratory care } \\
\text { centres }\end{array}$ & $\begin{array}{l}\text { To examine the feasibility } \\
\text { of adding a simple cessation } \\
\text { intervention to standard health } \\
\text { care services for TB patients. } \\
\text { A secondary question assessed } \\
\text { the outcomes of tobacco } \\
\text { cessation intervention by } \\
\text { measuring reported tobacco } \\
\text { use rates among patients in } \\
\text { the intervention centres at the } \\
\text { beginning and end of } 12 \text { months } \\
\text { of follow-up. }\end{array}$ & $\begin{array}{l}\text { According to baseline } \\
\text { questionnaire given to } 48 \mathrm{MA} \\
\text { prior to the trial, } 10(21 \%) \text { of the } \\
48 \mathrm{MA} \text { reported using some form } \\
\text { of tobacco, with no significant } \\
\text { difference between those in } \\
\text { the control and intervention } \\
\text { centres. Only } 8 \% \text { of participating } \\
\text { MA reported that they did not } \\
\text { allow smoking or snuff dipping } \\
\text { (10\%) at the health centre and } \\
22 \text { (46\%) reported almost always } \\
\text { advising their patients about } \\
\text { tobacco. Of all tobacco users } \\
\text { who were followed up, reported } \\
\text { cessation rates increased at each } \\
\text { intervention. A } 53.6 \% \text { ( } 165 / 308) \\
\text { abstinence rate at the end of } \\
\text { TB treatment among those } \\
\text { who were enrolled in a tobacco } \\
\text { cessation program vs } 14.3 \% \\
\text { (6/42) in a control group. }\end{array}$ & $\begin{array}{l}\text { No biochemical validation of the } \\
\text { reported high cessation rates. }\end{array}$ & $* * * *$ & * & *** \\
\hline
\end{tabular}


Review Paper

Table 2. Continued

\begin{tabular}{|c|c|c|c|c|c|c|c|c|c|}
\hline Author, year & Country & Study design & $\begin{array}{l}\text { Sample size/age/ } \\
\text { sex/type of sample }\end{array}$ & Study purpose & Findings & Limitations & Selection* & Comparability* & Outcome* \\
\hline $\begin{array}{l}\text { Gupte et al. } .^{31} \\
(2018)\end{array}$ & India & $\begin{array}{l}\text { Mixed- } \\
\text { methods study }\end{array}$ & $\begin{array}{l}\mathrm{n}=377 \text { patients ( } 84 \% \\
\text { men) with TB who } \\
\text { were current tobacco } \\
\text { users ( } 12 \% \text { smokers } \\
\text { only, } 78 \% \text { SLT users } \\
\text { only, } 10 \% \text { dual } \\
\text { tobacco users); } 25 \\
\text { DOTS providers ( } 80 \% \\
\text { women, mean age } 38 \\
\text { years) from } 27 \text { NG0- } \\
\text { run centres trained } \\
\text { to provide brief } \\
\text { advice and cessation } \\
\text { support in line with } \\
\text { Union guidelines }{ }^{49} \text {. } \\
\text { Setting: NG0-run } \\
\text { DOTS centres }\end{array}$ & $\begin{array}{l}\text { To determine: } 1 \text { ) the number } \\
\text { of centres that started } \\
\text { implementing brief tobacco } \\
\text { cessation programs; } 2 \text { ) the } \\
\text { characteristics of TB patients } \\
\text { who were current tobacco users, } \\
\text { stratified by type of tobacco; and } \\
\text { 3) tobacco use status, stratified } \\
\text { by TB category, following } \\
\text { tobacco cessation advice. }\end{array}$ & $\begin{array}{l}\text { A progressive trend in quit } \\
\text { rates was observed during the } \\
\text { treatment period (32\% among } \\
\text { new patients and 15\% among } \\
\text { those on retreatment, although } \\
\text { the quality of documentation } \\
\text { related to the brief advice and } \\
\text { cessation support provided by } \\
\text { DOTS providers declined. DOTS } \\
\text { providers also felt that they } \\
\text { had acquired the necessary } \\
\text { skills needed to implement the } \\
\text { intervention and suggested } \\
\text { important recommendations } \\
\text { including refresher training } \\
\text { courses, the possibility of } \\
\text { referring difficult patients and/or } \\
\text { people with multiple addictions } \\
\text { to experts and the need to } \\
\text { simplify documentation. }\end{array}$ & $\begin{array}{l}\text { Self-reported tobacco use status, } \\
\text { study design. }\end{array}$ & $* * *$ & & $* * *$ \\
\hline $\begin{array}{l}\text { Kanakia et al. }{ }^{32} \\
(2016)\end{array}$ & India & $\begin{array}{l}\text { Cross- } \\
\text { sectional study }\end{array}$ & $\begin{array}{l}\mathrm{n}=424 \text { presumptive } \\
\text { patients with } \mathrm{TB} \\
\text { aged }>18 \text { years, } \\
\text { mean age } 44 \text { years } \\
(\mathrm{SD}=16) \text {, smokers or } \\
\text { smokeless tobacco } \\
\text { users. } \\
\text { Setting: tertiary care } \\
\text { hospital }\end{array}$ & $\begin{array}{l}\text { To assess the burden of tobacco } \\
\text { use among presumptive TB } \\
\text { patients and their willingness } \\
\text { to avail of tobacco cessation } \\
\text { services at a tertiary care } \\
\text { hospital. }\end{array}$ & $\begin{array}{l}41.5 \% \text { (176/424) use tobacco } \\
\text { in previous } 1 \text { month (95\% Cl: } \\
36.9-46.3 \%), 75 \% \text { were smokers, } \\
25 \% \text { SLT form; } 53 \% \text { were willing } \\
\text { to avail themselves of tobacco } \\
\text { cessation services, if provided; } \\
\text { the willingness was higher } \\
\text { among those who had attempted } \\
\text { to quit and failed in the past } 1 \\
\text { year. }\end{array}$ & Not reported & $* * *$ & & $* *$ \\
\hline
\end{tabular}


Review Paper

Table 2. Continued

\begin{tabular}{|c|c|c|c|c|c|c|c|c|c|}
\hline Author, year & Country & Study design & $\begin{array}{l}\text { Sample size/age/ } \\
\text { sex/type of sample }\end{array}$ & Study purpose & Findings & Limitations & Selection* & Comparability* & Outcome* \\
\hline $\begin{array}{l}\text { Kaur et al. } .^{33} \\
(2013)\end{array}$ & India & $\begin{array}{l}\text { Intervention } \\
\text { study }\end{array}$ & $\begin{array}{l}\mathrm{n}=2879 \text { TB patients } \\
\text { (81.7\% with } \\
\text { pulmonary TB), } \\
1986 \text { males (69\%), } \\
\text { registered for D0TS } \\
\text { treatment; } 46.3 \% \\
\text { (1333/2879) of TB } \\
\text { patients were current } \\
\text { users of tobacco } \\
\text { - smokers and/or } \\
\text { smokeless tobacco } \\
\text { users, } 89.6 \% \text { males, } \\
\text { 40.8\% tobacco users } \\
\text { resided in urban } \\
\text { areas, and } 52.2 \% \\
\text { were from rural } \\
\text { areas. } \\
\text { Setting: primary } \\
\text { healthcare services }\end{array}$ & $\begin{array}{l}\text { The possibility and outcome of } \\
\text { integrating incorporating 'brief } \\
\text { advice' in tobacco cessation } \\
\text { intervention in TB patients who } \\
\text { are registered for treatment } \\
\text { under a TB control programme } \\
\text { and are tobacco users. }\end{array}$ & $\begin{array}{l}\text { While } 35.9 \% \text { of the TB patients } \\
\text { were smokers, } 39.1 \% \text { used } \\
\text { smokeless tobacco. } 61.9 \% \text { of } \\
\text { males and } 54.3 \% \text { of females } \\
\text { expressed their willingness to } \\
\text { quit. At the end of } 6 \text { months, } \\
67.3 \% \text { of patients who were } \\
\text { offered brief advice by the } \\
\text { D0TS provider and the same } \\
\text { advice was repeated during each } \\
\text { interaction with the TB patient } \\
\text { during the treatment period, } \\
\text { quit tobacco, while } 18.2 \% \text { re- } \\
\text { lapsed and } 14.5 \% \text { were lost to } \\
\text { follow-up. }\end{array}$ & $\begin{array}{l}\text { The confirmation regarding } \\
\text { quitting of tobacco use was } \\
\text { subjective assessment based } \\
\text { on the self-statement by the } \\
\text { patients. It was not validated by } \\
\text { performing tests such as urine } \\
\text { cotinine or carbon monoxide } \\
\text { analysis of breath. }\end{array}$ & $* * *$ & & $* *$ \\
\hline $\begin{array}{l}\text { Lam et al. }{ }^{34} \\
(2013)\end{array}$ & $\begin{array}{l}\text { South } \\
\text { Africa }\end{array}$ & $\begin{array}{l}\text { Cross- } \\
\text { sectional study }\end{array}$ & $\begin{array}{l}\mathrm{n}=707 \text { recently } \\
\text { diagnosed TB } \\
\text { patients, aged } \geq 18 \\
\text { years and diagnosed } \\
\text { with TB within the } \\
2 \text { months prior to } \\
\text { interview date; } 46 \% \\
\text { men, } 73 \% \text { HIV- } \\
\text { infected; } 6 \% \text { (46) } \\
\text { current smokers, } \\
38 \% \text { (267) former } \\
\text { smokers. } \\
\text { Setting: hospital }\end{array}$ & $\begin{array}{l}\text { Assessed the current and recent } \\
\text { smoking prevalence in those } \\
\text { with TB and TB-HIV co-infection } \\
\text { among hospitalized adults with } \\
\text { recently diagnosed TB. }\end{array}$ & $\begin{array}{l}138 \text { former smokers were } \\
\text { reclassified as current smokers } \\
\text { upon reporting smoking within } \\
2 \text { months before TB diagnosis, } \\
\text { resulting in } 26 \% \text { of current } \\
\text { smokers (184). By categorizing } \\
\text { smoking status solely based } \\
\text { on participants' self-reported } \\
\text { status at the time of interview, } \\
\text { the group of participants } \\
\text { who were current smokers } \\
\text { but quit at symptom onset } \\
\text { were misclassified as former } \\
\text { smokers, when in reality they } \\
\text { were smoking at the onset of TB } \\
\text { symptoms. }\end{array}$ & Not reported & $* * * *$ & & $* * *$ \\
\hline
\end{tabular}


Review Paper

Table 2. Continued

\begin{tabular}{|c|c|c|c|c|c|c|c|c|c|}
\hline Author, year & Country & Study design & $\begin{array}{l}\text { Sample size/age/ } \\
\text { sex/type of sample }\end{array}$ & Study purpose & Findings & Limitations & Selection* & Comparability* & Outcome* \\
\hline $\begin{array}{l}\text { Lin et al. }{ }^{35} \\
(2015)\end{array}$ & China & $\begin{array}{l}\text { Prospective } \\
\text { study }\end{array}$ & $\begin{array}{l}n=244 \text { patients with } \\
T B \text {, current smokers } \\
\text { from rural China. } \\
\text { Setting: public } \\
\text { health TB clinics }\end{array}$ & $\begin{array}{l}\text { To assess incorporation of } \\
\text { smoking cessation intervention } \\
\text { (providing information on the } \\
\text { harmful effects of tobacco } \\
\text { smoke and smoking and TB+ } \\
\text { every follow-up visit with } \\
\text { reinforcement health messages } \\
\text { and advice to quit) into routine } \\
\text { TB services. }\end{array}$ & $\begin{array}{l}\text { A majority }(81.6 \%) \text { had made } \\
\text { no attempt to quit before } \\
\text { the diagnosis of TB, } 95.9 \% \text { of } \\
\text { smokers were willing to quit. } \\
66.7 \% \text { (156/244) reported } \\
\text { abstinence at month } 6=\text { remain } \\
\text { abstinent at the end of TB } \\
\text { treatment. }\end{array}$ & $\begin{array}{l}\text { Findings may not be applicable } \\
\text { to female smokers, as there were } \\
\text { none in the study. Smoking } \\
\text { status was based on self-report. } \\
20.1 \% \text { of the TB patients } \\
\text { assigned to the SCI were not } \\
\text { seen at month } 6 \text {. Lack of a } \\
\text { control group. }\end{array}$ & *** & & $* *$ \\
\hline $\begin{array}{l}\text { Louwagie \&t } \\
\text { Ayo-Yusuf }{ }^{36} \\
\text { (2013) }\end{array}$ & $\begin{array}{l}\text { South } \\
\text { Africa }\end{array}$ & $\begin{array}{l}\text { Cross- } \\
\text { sectional study }\end{array}$ & $\begin{array}{l}n=1926[22 \% \\
(420 / 1924) \text { self- } \\
\text { reported smokers } \\
(37.6 \%) \text { males] over } \\
18 \text { years of age } \\
\text { seeking TB treatment. } \\
\text { Setting: TB clinics }\end{array}$ & Semi-structured questionnaires & $\begin{array}{l}\text { About half ( } 51.8 \% \text { ) of current } \\
\text { smokers had previously } \\
\text { attempted to quit in the past } 12 \\
\text { months (median quit duration } \\
21 \text { days), but very few patients } \\
\text { had made use of cessation aids } \\
\text { or services. The majority of } \\
\text { respondents believed tobacco } \\
\text { smoking was harmful for their } \\
\text { health ( } 90.5 \% \text { were aware of } \\
\text { the risk of lung cancer), but the } \\
\text { level of awareness regarding the } \\
\text { risk of stroke and heart attack } \\
\text { was lower ( } 48.5 \% \text { and } 38.2 \% \text {, } \\
\text { respectively), } 40 \% \text { noted that } \\
\text { smokers were more likely to get } \\
\text { TB and a third observed that } \\
\text { smoking worsens TB, and were } \\
\text { highly motivated to quit (median } \\
\text { score 9). }\end{array}$ & $\begin{array}{l}\text { The population of TB patients } \\
\text { is not representative of all TB } \\
\text { patients in the province or South } \\
\text { Africa. }\end{array}$ & $* * *$ & & $* *$ \\
\hline
\end{tabular}


Review Paper

Table 2. Continued

\begin{tabular}{|c|c|c|c|c|c|c|c|c|c|}
\hline Author, year & Country & Study design & $\begin{array}{l}\text { Sample size/age/ } \\
\text { sex/type of sample }\end{array}$ & Study purpose & Findings & Limitations & Selection* & Comparability* & Outcome* \\
\hline $\begin{array}{l}\text { Louwagie et } \\
\text { al. }^{37} \\
(2019)\end{array}$ & $\begin{array}{l}\text { South } \\
\text { Africa }\end{array}$ & $\begin{array}{l}\text { Mixed-method } \\
\text { study }\end{array}$ & $\begin{array}{l}\mathrm{n}=45 \text { patients with } \\
\text { TB ( } 82 \% \text { men, mean } \\
\text { age } 39.8 \text { years), } \\
\text { who smoked, drank } \\
\text { alcohol or did both, } \\
\text { and had not been } \\
\text { treated for TB for } \\
\text { more than one } \\
\text { month. } \\
\text { Setting: clinics }\end{array}$ & $\begin{array}{l}\text { Semi-structured questionnaire } \\
\text { to test the feasibility of the } \\
\text { ProLife programme (a brief } \\
\text { motivational intervention and } \\
\text { SMS-programme) by monitoring } \\
\text { fidelity to MI sessions and } \\
\text { assessing the proficiency of LHW } \\
\text { in facilitating the MI sessions. }\end{array}$ & $\begin{array}{l}\text { Multiple risk behaviour } \\
\text { interventions similar to the } \\
\text { ProLife programme can be } \\
\text { effective and sequentially } \\
\text { addressing smoking alongside } \\
\text { other interventions as used } \\
\text { in ProLife is preferable to } \\
\text { simultaneous interventions. Most } \\
\text { patients rated the MI sessions } \\
\text { as helpful, ascribed positive } \\
\text { attributes to their counselors, } \\
\text { and reported behavioral changes. } \\
\text { LHW: a) grasped the basic MI } \\
\text { spirit but failed to understand } \\
\text { specific MI techniques due to } \\
\text { insufficient specific practice, b) } \\
\text { viewed SMSs favourable, and } \\
\text { c) considered limited space and } \\
\text { privacy at the clinics as key } \\
\text { challenges. }\end{array}$ & $\begin{array}{l}\text { Small sample size. Social } \\
\text { desirability bias may have led to } \\
\text { overly positive feedback from } \\
\text { both LHW and TB patients: Self- } \\
\text { reported reductions in drinking } \\
\text { and smoking were not validated. }\end{array}$ & ** & & \\
\hline $\begin{array}{l}\text { Mariappan et } \\
\text { al. }^{38} \\
(2016)\end{array}$ & India & $\begin{array}{l}\text { A } \\
\text { community- } \\
\text { based cross- } \\
\text { sectional study }\end{array}$ & $\begin{array}{l}\mathrm{n}=235 \text { patients with } \\
\text { pulmonary TB; } 83 \\
(35.3 \%) \text { smokers at } \\
\text { the time of diagnosis, } \\
23(9.8 \%) \text { used SLT. } \\
\text { Setting: primary } \\
\text { health care centres }\end{array}$ & $\begin{array}{l}\text { To assess the prevalence and } \\
\text { pattern of tobacco use among } \\
\text { pulmonary TB patients residing } \\
\text { in urban Puducherry and to } \\
\text { study the association of various } \\
\text { sociodemographic factors with } \\
\text { current tobacco smoking and } \\
\text { current smokeless tobacco use. }\end{array}$ & $\begin{array}{l}30 \text { patients quit smoking and } \\
22 \text { patients reduced their } \\
\text { smoking status after being } \\
\text { diagnosed with TB and the rest } \\
37.3 \% \text { (31/83) maintained their } \\
\text { smoking status. Male patients } \\
\text { and having lower education } \\
\text { were significantly associated } \\
\text { with current smoking during TB } \\
\text { treatment. }\end{array}$ & Self-reported on tobacco use. & ** & & $* *$ \\
\hline
\end{tabular}


Review Paper

Table 2. Continued

\begin{tabular}{|c|c|c|c|c|c|c|c|c|c|}
\hline Author, year & Country & Study design & $\begin{array}{l}\text { Sample size/age/ } \\
\text { sex/type of sample }\end{array}$ & Study purpose & Findings & Limitations & Selection* & Comparability* & Outcome* \\
\hline $\begin{array}{l}\text { Navya et al. }{ }^{39} \\
(2019)\end{array}$ & India & $\begin{array}{l}\text { Mixed- } \\
\text { methods study } \\
\text { including a } \\
\text { quantitative } \\
\text { (cohort study) }\end{array}$ & $\begin{array}{l}\mathrm{n}=413 \text { patients; } \\
278(67.3 \%) \text { males, } \\
\text { mean age } 42.6 \text { years; } \\
335(81.1 \%) \text { with } \\
\text { pulmonary TB, } 320 \\
(77.5 \%) \text { new TB } \\
\text { cases, smokers and/ } \\
\text { or smokeless tobacco } \\
\text { users. } \\
\text { Setting: TB units } \\
\text { treated under } \\
\text { Revised National } \\
\text { Tuberculosis Control } \\
\text { Programme }\end{array}$ & $\begin{array}{l}\text { To: 1) report the extent of } \\
\text { documentation of tobacco and } \\
\text { alcohol usage data in the TB } \\
\text { treatment card, and 2) explore } \\
\text { the process, facilitators and } \\
\text { challenges in the linkage of } \\
\text { services for tobacco cessation } \\
\text { and alcohol abuse from the } \\
\text { perspective of health care } \\
\text { providers and adult patients } \\
\text { with TB. }\end{array}$ & $\begin{array}{l}\text { The documentation of the } \\
\text { tobacco use status was good but } \\
\text { not universally done. Tobacco } \\
\text { use was documented in } 322 \\
\text { ( } 78 \%) \text { of the TB treatment cards } \\
\text { reviewed. Among the } 86(21 \%) \\
\text { patients documented as current } \\
\text { tobacco users, } 16(19 \%) \text { were } \\
\text { linked to tobacco cessation } \\
\text { services while no linkage was } \\
\text { documented in the treatment } \\
\text { cards of } 46(53.3 \%) \text { patients. }\end{array}$ & $\begin{array}{l}\text { All of the new TB treatment } \\
\text { cards were not available for data } \\
\text { collection in the few Tuberculosis } \\
\text { Units of Dakshina Kannada } \\
\text { district. This would have led to } \\
\text { an over- or under-estimation } \\
\text { of the results. Data could be } \\
\text { validated for only a small subset } \\
\text { of the total study population due } \\
\text { to challenges in the two steps } \\
\text { for obtaining informed consent. }\end{array}$ & ** & & $* *$ \\
\hline $\begin{array}{l}\text { Ng et al. }{ }^{40} \\
(2008)\end{array}$ & Indonesia & $\begin{array}{l}\text { Cross- } \\
\text { sectional study }\end{array}$ & $\begin{array}{l}\mathrm{n}=239 \text { male TB } \\
\text { patients who } \\
\text { completed the DOTS- } \\
\text { based treatment } \\
\text { regimen; } 218 \text { (91.2\%) } \\
\text { were ever smokers } \\
\text { who had ever } \\
\text { smoked even a puff } \\
\text { of a cigarette. } \\
\text { Setting: lung clinics }\end{array}$ & $\begin{array}{l}\text { Study: 1) documents smoking } \\
\text { patterns among TB patients } \\
\text { before diagnosis, during } \\
\text { treatment and post treatment; 2) } \\
\text { identifies messages that health } \\
\text { professionals and DOTS providers } \\
\text { give their patients about } \\
\text { smoking; and 3) identifies factors } \\
\text { associated with smoking relapse } \\
\text { among TB patients. }\end{array}$ & $\begin{array}{l}\text { Only 11\% ( } \mathrm{n}=8 \text { ) remained daily } \\
\text { smokers while on TB treatment. } \\
\text { Relapsed smokers were } \\
\text { significantly younger and started } \\
\text { to smoke their first cigarette } \\
\text { earlier than quitters, more often } \\
\text { than quitters perceived that } \\
\text { smoking causes TB ( } \mathrm{p}=0.01 \text { ). } \\
\text { Only one-third of ex-TB patients } \\
\text { reported that they had been } \\
\text { advised to quit smoking by a } \\
\text { nurse, } 69.2 \% \text { received such } \\
\text { advice from a doctor. Receiving } \\
\text { a cessation message from one's } \\
\text { doctor was non-significantly } \\
\text { associated with a lower } \\
\text { likelihood of smoking relapse } \\
\text { (OR=0.60). }\end{array}$ & $\begin{array}{l}\text { Potential of recall bias when } \\
\text { asking ex-TB patients about } \\
\text { smoking levels. Our intention } \\
\text { was to assess general levels of } \\
\text { smoking at different points of } \\
\text { time. Some of these former } \\
\text { patients resumed smoking at the } \\
\text { same levels as they did prior to } \\
\text { illness, while others smoked at } \\
\text { lower levels, mistakenly thinking } \\
\text { that smoking at such levels is } \\
\text { relatively safe. }\end{array}$ & ** & & $* * *$ \\
\hline
\end{tabular}


Review Paper

Table 2. Continued

\begin{tabular}{|c|c|c|c|c|c|c|c|c|c|}
\hline Author, year & Country & Study design & $\begin{array}{l}\text { Sample size/age/ } \\
\text { sex/type of sample }\end{array}$ & Study purpose & Findings & Limitations & Selection* & Comparability* & Outcome* \\
\hline $\begin{array}{l}\text { Nichter et al. }{ }^{41} \\
(2016)\end{array}$ & Indonesia & $\begin{array}{l}\text { Prospective } \\
\text { two-arm } \\
\text { intervention } \\
\text { study }\end{array}$ & $\begin{array}{l}\mathrm{n}=87 \text { newly } \\
\text { diagnosed male TB } \\
\text { patients who smoked } \\
\text { undergoing DOTS for } \\
\text { TB at home. } \\
\text { Setting: home }\end{array}$ & $\begin{array}{l}\text { To assess the impact of TB- } \\
\text { specific quit smoking messages } \\
\text { in the TB clinic and at home. }\end{array}$ & $\begin{array}{l}\text { Although most patients with TB } \\
\text { quit smoking when undertaking } \\
\text { treatment, nearly a third resume } \\
\text { smoking when treatment is } \\
\text { completed and this percentage } \\
\text { increases to } 40 \% \text { six months } \\
\text { later. Many former patients } \\
\text { and their family members do } \\
\text { not consider low-to-moderate } \\
\text { level smokers to be real smokers, } \\
\text { particularly those who have } \\
\text { reduced their smoking from one } \\
\text { to two packs a day to just a few } \\
\text { sticks. }\end{array}$ & Self-report; small sample size. & *** & $*$ & *** \\
\hline $\begin{array}{l}\text { Pradeepkumar } \\
\text { et al. }{ }^{42} \\
(2008)\end{array}$ & India & $\begin{array}{l}\text { Cross- } \\
\text { sectional study }\end{array}$ & $\begin{array}{l}\mathrm{n}=215 \text { patients with } \\
\text { TB (males); mean } \\
\text { age } 49.0 \text { years; } \\
94.4 \%(203 / 215) \\
\text { were ever tobacco } \\
\text { users (smokers and/ } \\
\text { or smokeless tobacco } \\
\text { users). } \\
\text { Setting: TB units }\end{array}$ & $\begin{array}{l}\text { 1) To document tobacco use } \\
\text { patterns among TB patients at } \\
\text { different time points before } \\
\text { diagnosis, during treatment } \\
\text { and following treatment; } 2 \text { ) to } \\
\text { examine how often cessation } \\
\text { messages are given to TB } \\
\text { patients by health staff and } \\
\text { DOTS providers; } 3 \text { ) to investigate } \\
\text { how the messages received are } \\
\text { understood; and 4) to identify } \\
\text { critical points of time when } \\
\text { cessation messages need to be } \\
\text { given based on when relapse is } \\
\text { most likely to occur. }\end{array}$ & $\begin{array}{l}79 \% \text { quit within } 1 \text { week of } \\
\text { diagnosis. During treatment } \\
\text { period there were only } 12.4 \% \text { of } \\
\text { persistent smokers and } 87.6 \% \text { of } \\
\text { initial quitters of whom } 64.2 \% \\
\text { stayed permanent quitters at } \\
\text { the end of } 6 \text { months. Of the } 48 \\
\text { relapsed TB patients, one third } \\
\text { relapsed within the first 2-3 } \\
\text { months of treatment, another } \\
\text { third within the next } 3 \text { months } \\
\text { of treatment and } 21 \% \text { within } \\
\text { the } 3 \text { months of treatment. More } \\
\text { than half of all relapses occurred } \\
\text { during the early months of } \\
\text { treatment among patients whose } \\
\text { D0TS providers were non-health } \\
\text { staff. Among patients who had } \\
\text { D0TS providers who were health } \\
\text { staff, most relapses occurred } \\
\text { after completion of treatment. }\end{array}$ & $\begin{array}{l}\text { The data are robust enough } \\
\text { to support the conclusions } \\
\text { about the need for: 1) repeated } \\
\text { exposure of TB patients to } \\
\text { smoking cessation intervention, } \\
\text { and 2) interventions for former } \\
\text { and quitting smokers to } \\
\text { encourage sustained cessation. }\end{array}$ & $* *$ & & $* * *$ \\
\hline
\end{tabular}


Review Paper

Table 2. Continued

\begin{tabular}{|c|c|c|c|c|c|c|c|c|c|}
\hline Author, year & Country & Study design & $\begin{array}{l}\text { Sample size/age/ } \\
\text { sex/type of sample }\end{array}$ & Study purpose & Findings & Limitations & Selection* & Comparability* & Outcome* \\
\hline $\begin{array}{l}\text { Sereno et al. }{ }^{43} \\
(2012)\end{array}$ & Brazil & $\begin{array}{l}\text { Mixed- } \\
\text { methods study }\end{array}$ & $\begin{array}{l}\mathrm{n}=16 \text { D0TS providers } \\
\text { and supervising } \\
\text { physicians; } 15 / 16 \\
\text { women, mean } \\
\text { age } 45.8 \text { years; } 20 \\
\text { patients, current } \\
\text { smokers, completed } \\
\text { the follow-up } \\
\text { questionnaire and } \\
\text { urine testing for } \\
\text { cotinine. } \\
\text { Setting: primary } \\
\text { health care centres }\end{array}$ & $\begin{array}{l}\text { A pilot study to determine } \\
\text { whether DOTS workers could } \\
\text { be trained to deliver smoking } \\
\text { cessation counselling and } \\
\text { referral interventions, to identify } \\
\text { potential barriers to a full-scale } \\
\text { randomized controlled trial on } \\
\text { the effectiveness of integrated } \\
\text { smoking cessation in DOTS, } \\
\text { and to determine whether TB } \\
\text { patients who smoke would agree } \\
\text { to participate in such a program. }\end{array}$ & $\begin{array}{l}\text { Their self-rated ability to } \\
\text { communicate the } 5 \text { As improved } \\
\text { significantly between pre- } \\
\text { training and post-training, and } \\
\text { to provide smoking cessation } \\
\text { support improved without } \\
\text { statistical significance. There is a } \\
\text { dose-response relation between } \\
\text { the session length of person-to- } \\
\text { person contact and successful } \\
\text { treatment outcomes. However, } \\
\text { even minimal interventions } \\
\text { lasting less than } 3 \text { min increase } \\
\text { overall tobacco abstinence rates. } \\
\text { Person-to-person treatment } \\
\text { delivered for four or more } \\
\text { sessions appears to be especially } \\
\text { effective in increasing abstinence } \\
\text { rates. }\end{array}$ & $\begin{array}{l}\text { The confirmation regarding } \\
\text { quitting of tobacco use was } \\
\text { subjective assessment based } \\
\text { on the self-statement by the } \\
\text { patients. It was not validated by } \\
\text { performing tests such as urine } \\
\text { cotinine or carbon monoxide } \\
\text { analysis of breath. }\end{array}$ & ** & & * \\
\hline $\begin{array}{l}\text { Shangase et } \\
\text { al. } .^{4} \\
(2017)\end{array}$ & $\begin{array}{l}\text { South } \\
\text { Africa }\end{array}$ & $\begin{array}{l}\text { Qualitative } \\
\text { research } \\
\text { design }\end{array}$ & $\begin{array}{l}20 \text { inpatients (15 } \\
\text { men) at a TB hospital } \\
\text { who self-identified } \\
\text { as smokers and had } \\
\text { drug-resistant (DR) } \\
\text { TB. Age ranged from } \\
18 \text { to } 70 \text { years. } \\
\text { Setting: hospital }\end{array}$ & $\begin{array}{l}\text { What are the barriers to } \\
\text { smoking cessation among DR-TB } \\
\text { inpatients in South Africa? }\end{array}$ & $\begin{array}{l}\text { Using smoking as a coping } \\
\text { mechanism was identified as an } \\
\text { addiction-related barrier (for } \\
\text { more details, see Table 3). Lack } \\
\text { of access to smoking cessation } \\
\text { interventions is a key structural- } \\
\text { level barrier highlighted in this } \\
\text { study. }\end{array}$ & $\begin{array}{l}\text { This study recruited participants } \\
\text { who were inpatients and were } \\
\text { being treated for drug-resistant } \\
\text { tuberculosis; therefore, the } \\
\text { generalizability of the results to } \\
\text { outpatients is limited. }\end{array}$ & $* * *$ & & $* * *$ \\
\hline
\end{tabular}


Review Paper

Table 2. Continued

\begin{tabular}{|c|c|c|c|c|c|c|c|c|c|}
\hline Author, year & Country & Study design & $\begin{array}{l}\text { Sample size/age/ } \\
\text { sex/type of sample }\end{array}$ & Study purpose & Findings & Limitations & Selection* & Comparability* & Outcome* \\
\hline $\begin{array}{l}\text { Shin et al. }{ }^{45} \\
(2012)\end{array}$ & China & $\begin{array}{l}\text { Qualitative } \\
\text { study }\end{array}$ & $\begin{array}{l}\text { Randomly selected } \\
\text { hospitalized patients } \\
\text { from an inpatient } \\
\text { registration list and } \\
\text { conveniently selected } \\
\text { patients attending } \\
\text { an outpatient clinic } \\
\text { for screening, aged } \\
\geq 18 \text { years, had begun } \\
\text { treatment for TB in } \\
\text { the past } 6 \text { months, } \\
\text { and had smoked } \\
\text { any time during } \\
\text { the } 30 \text { days prior to } \\
\text { diagnosis with TB. } \\
\text { Two focus group } \\
\text { discussions of } 17 \\
\text { TB physicians and } \\
\text { five focus groups } \\
\text { of } 39 \text { patients were } \\
\text { conducted. } \\
\text { Setting: hospital }\end{array}$ & $\begin{array}{l}\text { To compare perceptions about } \\
\text { smoking cessation among TB } \\
\text { patients and their physicians. }\end{array}$ & $\begin{array}{l}\text { Patients who were advised to } \\
\text { quit smoking by their physicians } \\
\text { after diagnosis with TB were } \\
\text { likely to progress in their stage } \\
\text { membership and attempt to quit } \\
\text { smoking. Patients and physicians } \\
\text { were concerned about the } \\
\text { likelihood of smoking relapse } \\
\text { after patients recovered from } \\
\text { TB. Physicians had low levels } \\
\text { of knowledge regarding the } \\
\text { effect of smoking on TB. Many } \\
\text { doctors, particularly those who } \\
\text { smoked, did not view smoking } \\
\text { cessation as an integral part of } \\
\text { TB treatment. }\end{array}$ & $\begin{array}{l}\text { The focus groups were conducted } \\
\text { in one TB hospital in Beijing, } \\
\text { China. The findings may not be } \\
\text { generalizable to TB patients and } \\
\text { providers in other TB facilities. } \\
\text { Many physicians, particularly } \\
\text { those who were smokers, did } \\
\text { not view smoking cessation as } \\
\text { an integral part of TB treatment } \\
\text { and did not believe that their } \\
\text { patients would accept smoking } \\
\text { cessation counselling. }\end{array}$ & * & & ** \\
\hline $\begin{array}{l}\text { Siddiquea et } \\
\text { al. }{ }^{46} \\
(2013)\end{array}$ & Bangladesh & Cohort study & $\begin{array}{l}n=615 \text { current } \\
\text { smokers; } 99 \% \text { of } \\
\text { men, mean age } 38 \\
\text { years (range 16-77); } \\
\text { final evaluation } \\
\text { possible in } 562 \\
\text { patients. } \\
\text { Setting: peri-urban } \\
\text { TB centres }\end{array}$ & $\begin{array}{l}\text { To determine whether a modified } \\
\text { version of The Union's ABC } \\
\text { guideline ( } 5-10 \text { min of brief } \\
\text { advice to quit smoking) in } \\
\text { Bangladesh was effective in } \\
\text { promoting smoking cessation } \\
\text { among TB patients and } \\
\text { determinants associated with } \\
\text { smoking cessation }\end{array}$ & $\begin{array}{l}\text { Overall, 82\% (464/562) of } \\
\text { smokers had quit and the quit } \\
\text { rate increased progressively } \\
\text { from the first follow-up to the } \\
\text { end of TB treatment (usually } \\
\text { at month } 6 \text { or 8). Patients were } \\
\text { considered to have quit smoking } \\
\text { if they reported that they had } \\
\text { not smoked tobacco in the past } \\
15 \text { days. }\end{array}$ & $\begin{array}{l}\text { This was a pilot study and may } \\
\text { have generated an exceptionally } \\
\text { high level of enthusiasm for } \\
\text { counselling that led to higher } \\
\text { quit rates. Such enthusiasm may } \\
\text { not be sustained over the long } \\
\text { term if introduced more widely. } \\
\text { Self-reporting of quitting. }\end{array}$ & $* * *$ & & $* * *$ \\
\hline
\end{tabular}


Review Paper

Table 2. Continued

\begin{tabular}{|c|c|c|c|c|c|c|c|c|c|}
\hline Author, year & Country & Study design & $\begin{array}{l}\text { Sample size/age/ } \\
\text { sex/type of sample }\end{array}$ & Study purpose & Findings & Limitations & Selection* & Comparability* & Outcome* \\
\hline $\begin{array}{l}\text { Tsai et al. }{ }^{47} \\
(2016)\end{array}$ & Taiwan & $\begin{array}{l}\text { Cross- } \\
\text { sectional } \\
\text { retrospective } \\
\text { study }\end{array}$ & $\begin{array}{l}\mathrm{n}=123 \text { patients with } \\
\text { TB at a rural district } \\
\text { hospital (78\% of } \\
\text { men, mean age } 61.4 \\
\text { years, } 45[46.9 \%] \\
\text { smokers before TB } \\
\text { diagnosis). } \\
\text { Setting: TB } \\
\text { outpatient clinic in a } \\
\text { local hospital }\end{array}$ & $\begin{array}{l}\text { To evaluate and compare } \\
\text { changes in cigarette smoking } \\
\text { and health-promoting } \\
\text { behaviours reported before and } \\
\text { after TB diagnosis among adults } \\
\text { in a disadvantaged region. }\end{array}$ & $\begin{array}{l}\text { The percentage of participants } \\
\text { who smoked decreased to } \\
30.2 \%(29 / 123) \text { after receiving } \\
\text { or completing TB treatment, } \\
\text { determinants for current } \\
\text { health-promoting behaviours } \\
\text { were chronic disease }(b=-0-.25 \text {; } \\
p=0.005) \text { and completion of TB } \\
\text { treatment ( } b=0.23 ; p=0.007) \text {. } \\
\text { A high prevalence of cigarette } \\
\text { smoking and low levels of } \\
\text { health-promoting behaviours } \\
\text { were observed before the } \\
\text { diagnosis and during or after } \\
\text { completing TB treatment. }\end{array}$ & $\begin{array}{l}\text { Limited generalisability } \\
\text { (relatively uneducated patients } \\
\text { from rural hospital were } \\
\text { recruited), design of the study } \\
\text { and self-reporting of certain } \\
\text { health-related behaviours. }\end{array}$ & ** & & ** \\
\hline $\begin{array}{l}\text { Warsi et al. }{ }^{48} \\
(2019)\end{array}$ & $\begin{array}{l}\text { Banglades, } \\
\text { Nepal, and } \\
\text { Pakistan }\end{array}$ & $\begin{array}{l}\text { Mixed- } \\
\text { methods study }\end{array}$ & $\begin{array}{l}25 \text { semi-structured } \\
\text { interviews and } \\
12 \text { Focus Group } \\
\text { Discussion across } \\
\text { Bangladesh, Nepal, } \\
\text { and Pakistan, and } \\
\text { administered the } \\
\text { adapted a UK } \\
\text { National Centre for } \\
\text { Smoking Cessation } \\
\text { and Training } \\
\text { questionnaire to } \\
36 \text { TB health workers } \\
\text { (HWs) (100\% in } \\
\text { Pakistan and 95\% in } \\
\text { Bangladesh did not } \\
\text { smoke). }\end{array}$ & $\begin{array}{l}\text { A brief behaviour support } \\
\text { intervention (a flip book, a } \\
\text { leaflet and a poster) was tested } \\
\text { with patients and health } \\
\text { workers. Health workers received } \\
\text { training in delivering a } \\
15-20 \text { min intervention. }\end{array}$ & $\begin{array}{l}\text { Patients were not opposed to } \\
\text { being approached about their } \\
\text { smoking habit, although HW } \\
\text { expressed concerns that women } \\
\text { might not admit to tobacco use } \\
\text { and that asking about tobacco } \\
\text { use was a sensitive issue. HW } \\
\text { ability to deliver tobacco } \\
\text { cessation behavioural support } \\
\text { to patients was hindered by } \\
\text { a lack of knowledge about } \\
\text { tobacco and TB interaction, } \\
\text { low understanding of tobacco } \\
\text { cessation, and poor patient } \\
\text { communication skills. Additional } \\
\text { barriers shown in Table } 3 \text {. }\end{array}$ & $\begin{array}{l}\text { Use of multiple data sources } \\
\text { (health workers, policymakers } \\
\text { and patients), multiple methods } \\
\text { (focus groups, interviews and } \\
\text { questionnaire) and drawing on } \\
\text { the theoretical framework of } \\
\text { COM-B to guide data collection } \\
\text { and analysis. }\end{array}$ & $* * *$ & & *** \\
\hline
\end{tabular}

*The Newcastle-Ottawa Scale (NOS) for Assessing the Quality of Nonrandomized Studies". 


\section{Table 3. Facilitators of and barriers to smoking cessation/TDT in patients with TB of LMICs identified in included studies}

\section{Facilitators}

Confirmed TB diagnosis more likely than other respiratory conditions ${ }^{14}$

Living in urban areas, office jobs, being single significantly increased the intention to quit smoking ${ }^{22}$

Combined interventions ${ }^{13,19,20}$

Brief, but repeated interventions, motivation, brochures ${ }^{15-17,28,31}$

Tobacco-free healthcare facilities ${ }^{25}$

Time from waking to first cigarette of >30 min, routine screening for smoking, having a smoke-free home and display of 'no smoking' sign at home, regular reminders and encouragement of by family members to quit smoking ${ }^{25}$

Willingness to quit - higher in those with previous attempt(s) in the past year ${ }^{32}$

Incorporating of training in brief advice into existing training of DOTS providers ${ }^{33}$

Personalized behavioural counselling incorporated into routine TB services ${ }^{24,35,43,46}$

High level of awareness regarding smoking risk for health ${ }^{36}$

Multiple risk behaviour interventions ${ }^{37}$

Repeated tobacco use intervention follow-up at a minimum of 6 months after end of TB treatment ${ }^{30,43}$

Providing intervention not only at a health facility but also on a daily basis at community level by health volunteers ${ }^{46}$

\section{Barriers}

High nicotine dependence ${ }^{18}$

Misclassification of current smokers as former smokers at the time of TB diagnosis (= quit smoking at the onset of TB symptoms ${ }^{34}$ )

Limited space and privacy at the clinics ${ }^{37}$

Male gender, lower education ${ }^{38}$

Daily smoking of more than 15 cigarettes/bidis at the time of diagnosis ${ }^{41}$

Patients' cards without the provision to include about brief advice on smoking cessation given which has been mentioned in the TB treatment guidelines; lack of coordination between the TB treatment programme and tobacco cessation ${ }^{39,43}$

Identified in patients with drug-resistant TB:

- Addiction-related personal barriers - initiating smoking as teenagers, craving for a cigarette, smoking as part of the daily routine, failed quit attempts (relapses when feeling better)

- Structural (institutional) factors - lack of impact of health education sessions, lack of extramural activities when on hospital admission, lack of access to smoking cessation interventions (unaware of any available aids to stop smoking or NRT), easy access to cigarettes within a hospital setting (from staff, peers, visitors, shops close to hospital, hospital café) ${ }^{44}$

- Non-addiction-related personal barriers - lack of knowledge about quit strategies, lack of willpower to quit, psychosocial stress, peer smokers' influence

Barriers for HW to provide BSS: institutional lack of resources (insufficient space, high patient load, no reporting/recording of tobacco, overwork) and an absence of professional support through monitoring and evaluation ${ }^{48}$

\section{Possible barriers to smoking cessation/TDT - patients\% staff"s knowledge, attitudes}

Lack of resources (human, financial), low level of education of health providers on smoking cessation ${ }^{21}$

Beliefs that smoking is fun, calms nerves, relieves all life stresses ${ }^{23}$

Stigma (especially in women to admit using tobacco) 26,48

Tolerance of smoking or snuff dipping at a health centre by medical assistants providing $\mathrm{SCl}$, smoking staff ${ }^{30}$

Not considering low-to-moderate level smokers to be real smokers, particularly those who have reduced their smoking from one to two packs a day to just a few sticks ${ }^{41}$

Less knowledge that smoking increases risk of stroke and heart attack ${ }^{36}$

Physicians' low levels of knowledge regarding the effect of smoking on TB - particularly physicians who smoked did not view smoking cessation as an integral part of TB treatment ${ }^{45}$

Decrease of initial enthusiasm for counselling (seen in pilot studies) over the long-term if introduced more widely ${ }^{46}$

Relying on the fact that the diagnosis of TB alone will lead to a more significant decrease in the prevalence of smoking among patient with $\mathrm{TB}^{47}$ 
Table 4. Factors associated with smoking relapse among TB patients in LMICs (N=6) identified in included studies

\author{
Short duration of pharmacotherapy ${ }^{19}$ \\ Socio-cultural influences (i.e. family/friends smokers) ${ }^{26}$ \\ Brief advice focused only on smoking could lead to a higher rate of SLT relapse seen as a form of harm reduction ${ }^{29}$ \\ Receiving a disease-specific cessation message - associated with a lower likelihood of smoking relapse ${ }^{40}$ \\ Perception of low-moderate level smoking as harmless ${ }^{41}$ \\ Period of follow-up: increase in relapses within the 6 months of treatment and within the 3-6 months following treatment ${ }^{40-42}$
}

Table 5. Risk of bias assessments assessed in randomized controlled studies

\begin{tabular}{|c|c|c|c|c|c|c|c|}
\hline Author, year & $\begin{array}{l}\text { Random } \\
\text { sequence } \\
\text { generation } \\
\text { (selection } \\
\text { bias) }\end{array}$ & $\begin{array}{l}\text { Allocation } \\
\text { concealment } \\
\text { (selection } \\
\text { bias) }\end{array}$ & $\begin{array}{c}\text { Blinding } \\
\text { participants/ } \\
\text { personnel } \\
\text { (performance } \\
\text { bias) }\end{array}$ & $\begin{array}{l}\text { Blinding } \\
\text { outcome } \\
\text { assessment } \\
\text { (detection } \\
\text { bias) }\end{array}$ & $\begin{array}{l}\text { Incomplete } \\
\text { outcome data } \\
\text { (attrition } \\
\text { bias) }\end{array}$ & $\begin{array}{l}\text { Selective } \\
\text { reporting } \\
\text { (reporting } \\
\text { bias) }\end{array}$ & Other bias \\
\hline Aryanpur et al. ${ }^{13}$ (2016) & Low & Low & Low & Low & Low & Low & Low \\
\hline Goel et al. ${ }^{15}$ (2017) & Low & Low & Low & Low & Low & Low & Low \\
\hline Kumar et al. ${ }^{16}$ (2017) & Low & Low & Low & High & Low & Low & High \\
\hline Louwagie et al. ${ }^{17}$ (2014) & Low & Low & Low & Low & Low & Low & Low \\
\hline Sharma et al. ${ }^{19}(2018)$ & Low & Low & Low & Low & Low & Low & Low \\
\hline Siddiqi et al. ${ }^{20}$ (2013) & Low & Low & Low & Low & Low & Low & Low \\
\hline
\end{tabular}

Some smokers' characteristics were found to be facilitators too: willingness to quit - higher in those with previous attempt(s) in the past year ${ }^{32}$, time from waking to the first cigarette of $>30 \mathrm{~min}$, having a smoke-free home, display of 'no smoking' sign at home ${ }^{25}$, and a high level of awareness regarding smoking risk for health ${ }^{36}$. Other identified facilitators were: living in urban areas, office jobs, and being single, which significantly increased the intention to quit smoking ${ }^{22}$.

Facilitators originating in the healthcare system were the following: incorporating training in brief advice into existing training of DOTS providers ${ }^{33}$, multiple risk behavior interventions ${ }^{37}$, and tobaccofree healthcare facilities ${ }^{25}$. Finally, providing intervention not only at a health facility but also on a daily basis at community level by health volunteers facilitated smoking cessation ${ }^{46}$.

\section{Barriers to smoking cessation/TDT in patients with TB of LMICs}

Barriers to smoking cessation/TDT in patients with TB of LMICs are presented in Table 3.

Male gender, lower education, high nicotine dependence and daily smoking of more than 15 cigarettes/bidis at the time of diagnosis, may be marked as non-influenceable risk factors that are negatively associated with success in smoking cessation/TDT ${ }^{18,38,42}$. Possible patients' barriers to quit smoking may be less knowledge that smoking increases risk of cardiovascular diseases ${ }^{36}$ and their beliefs that smoking is fun and helps to deal with stress $^{23}$.

The qualitative study of Shangase et al. ${ }^{44}$ conducted in patients with drug-resistant TB in South Africa found 2 categories of barriers to smoking cessation in patients with drug-resistant TB: 1) personal factors including addiction-related barriers (initiating smoking as teenagers, craving for a cigarette, smoking as part of the daily routine, failed quit attempts - relapses when feeling better) and non-addiction-related barriers (lack of knowledge about quit strategies, lack of willpower to quit, psychosocial stress, peer smokers' influence); and 2) structural (institutional) factors (lack of impact of health education sessions, lack of extramural activities when on hospital admission, lack of access to smoking cessation interventions (unaware of any available aids to stop smoking or NRT), easy access to cigarettes within a hospital setting (from staff, peers, visitors, shops close to hospital, hospital café). 
Several barriers were connected to the healthcare system itself: limited space and privacy at the clinics ${ }^{37}$, lack of coordination between the TB treatment programme and tobacco cessation ${ }^{39,43}$, lack of resources (human, financial), low level of education of health providers on smoking cessation ${ }^{21}$, tolerance of smoking or snuff dipping at a health centre by medical assistants providing SCI, and smoking staff ${ }^{30}$.

Regarding HW, barriers to provide BSS were as follows: institutional lack of resources (insufficient space, high patient load, no reporting/recording of tobacco, overwork), an absence of professional support through monitoring and evaluation ${ }^{48}$ or misclassification of current smokers as former smokers at the time of TB diagnosis (= quit smoking at the onset of TB symptoms $)^{34}$. Low level of education of health providers on smoking cessation ${ }^{21}$, e.g. relying on the fact that the diagnosis of TB alone will lead to a more significant decrease in the prevalence of smoking among patients with $\mathrm{TB}^{47}$, and decrease of initial enthusiasm for counselling over the longterm ${ }^{46}$, may be barriers to provide SCI.

Staff knowledge regarding the effect of smoking on TB, as well as attitudes to smoking cessation may have an impact in providing smoking cessation/TDT within TB care $^{45,48}$. Shin et al. ${ }^{45}$ in their qualitative study pointed out that mainly those physicians who smoked did not view smoking cessation as an integral part of TB treatment. Other barriers were not considering low-to-moderate level smokers to be real smokers, particularly those who have reduced their smoking from one to two packs a day to just a few sticks ${ }^{41}$, and less knowledge that smoking increases risk of stroke and heart attack ${ }^{36}$.

Another important barrier is mentioned in the Boeckmann et al. ${ }^{26}$ and Warsi et al. ${ }^{48}$ studies - asking about tobacco use was perceived a sensitive issue, especially among women who may not admit to tobacco use.

Table 4 shows factors associated with smoking relapse among TB patients in LMICs. $\mathrm{Ng}$ et al. ${ }^{40}$ conducted qualitative interviews with TB patients and concluded that the majority of daily smokers quit smoking when diagnosed with TB; however, over one in three of those patients relapsed within 6 months of TB treatment completion. Similarly, Pradeepkumar et al. ${ }^{42}$ and Nichter et al. ${ }^{41}$ found that most relapses occurred after completion of treatment.
Short duration of pharmacotherapy might influence the number of patients who quit smoking, according to the randomized controlled study of Sharma et al. ${ }^{18}$. Possessing a disease-specific cessation message and focusing on all forms of tobacco use may decrease the probability of tobacco-dependence relapse $\mathrm{e}^{29,40}$.

\section{DISCUSSION}

\section{Statement of principal findings}

The studies included in this narrative literature review highlighted the feasibility and efficacy of incorporating brief advice as well as specialized treatment for smokers into TB care. Based on the findings from the selected studies and identification of factors affecting successful quitting, we propose a summary of implications for practice regarding smoking cessation or TDT in patients with lung TB in LMICs in the following paragraphs.

Tobacco-free TB centres and non-smoking staff are a condition sine qua non to support their patients in quitting. The centres' staff members should have an opportunity to treat their potential tobacco dependence or not to smoke during their working hours (e.g. to reduce withdrawal symptoms by nicotine replacement therapy $)^{25}$.

The staff should understand the importance of quitting smoking for TB prognosis, of providing brief interventions, of their own non-smoking status; regular refresher training session should be arranged and made available.

In $\mathrm{TB}$ centres, a brief, repeated and empathic intervention should be provided to all patients with TB who smoke. It is possible that a majority can quit smoking when diagnosed with $\mathrm{TB}^{40}$ or at the time of onset of TB symptoms ${ }^{34}$. Support for these patients should be part of routine care. They would benefit from regular monitoring of their withdrawal symptoms (WSs) and from an offer of pharmacotherapy in the case of intensive WSs, and brief support at each session within their respective TB centres. Motivational intervention should increase the number of patients quitting in the future. Empathic intervention increases the probability that the majority of patients will admit smoking. A potential gender barrier should also be taken into account ${ }^{26}$.

While it may seem unnecessary to measure CO levels in patients with suspected TB at the first consultation to verify their smoking status ${ }^{27}$, such a 
strategy could help as bio-feedback for patients who are quitting.

All patients in TB centres who smoke should be educated, through a brief intervention, about the risks of smoking associated with their disease and the importance of the 'not-even-one-puff' rule, because a higher level of awareness implies a higher probability of quitting and a lower one a tendency to relapse ${ }^{36,40}$. Likewise, patients should be told that use of smokeless tobacco is a potential factor for smoking relaps $\mathrm{e}^{29}$. Screening for smoke-free homes and recommendations to create them should be part of routine brief advice in smoking cessation.

Health volunteers may play a most important role in daily provision of intervention outside of health facilities directly in patients' communities ${ }^{46}$.

Tobacco-dependence treatment ranges from brief advice to intensive behavioural support together with pharmacological treatment ${ }^{7}$. It has been proven by RTGs that behavioural support combined with first-line pharmacotherapy (bupropion and nicotine replacement therapy) is effective in achieving prolonged abstinence at six months in adult TB patients participating in TB programmes in $\mathrm{LMICs}^{13,19,20}$. One of the possible less expensive pharmacotherapy options is cytisine, whose efficacy compares to that of currently licensed products. A study from Bangladesh ${ }^{8}$ may bring interesting findings; two face-to-face behavioural support sessions will be delivered and cytisine (active arm) or matching placebo (control arm) will be administered in a 25-day course. The success rate may depend on pharmacotherapy duration (at least 3 months) as well as on the type of intervention provided. A brief motivational session (15-20 $\mathrm{min})$ and the $\mathrm{ABC}$ approach $(\mathrm{A}=\mathrm{ask}, \mathrm{B}=$ brief advice, $\mathrm{C}=$ cessation support) are more effective than only a smoking cessation message. The specialized TDT should be provided by a trained doctor, nurse, psychologist or another health care provider, with such a specialist ideally available in each TB centre ${ }^{49}$.

Several months' follow-up after TB treatment completion with brief behavioural support and offer of pharmacotherapy in the case of a lapse or early relapse should be available as prevention of relapse in abstaining patients. A high number of patients relapsed 3-6 months after completion of TB treatment ${ }^{40,42}$.
It is critical that national policymakers support effective tobacco control policies developed by the World Health Organization (WHO) Framework Convention of Tobacco Control (FCTC). According to the WHO MPOWER policy package, the main effective strategies designed to reduce the prevalence of tobacco use in the general population include those affecting the availability of tobacco products (taxes, advertising), minimizing exposure to tobacco smoke (smoke-free public indoor spaces without exception) and offering specialized help. Limiting bans on tobacco advertising and the ease of access to cheap tobacco, often in a single cigarette form, enhance barriers to quit ${ }^{50}$.

\section{Limitations and strengths}

Although we conducted quality assessment of eligible studies, this is not a systematic review. Heterogeneous study designs made it impossible to conduct a metaanalysis and to assess the importance of individual factors in the quit process. However, this review maps and summarizes the available data on the topic, so that the formulated barriers and suggested facilitators can be identified for clinicians and policymakers to use. This summarized evidence could facilitate implementation of TDT in patients with TB in LMICs as an underused opportunity to significantly improve TB treatment outcomes and overall health.

\section{Implications for policy, practice and research}

Effective TDT provided by trained healthcare professionals is based on the same pillars, regardless of country or socioeconomic status. These include: a brief intervention as a routine part of healthcare; appropriately adapted information materials about the harmfulness of smoking in relation to TB and about the options in a smoking cessation programme; trained non-smoking staff in specialized centres; availability of pharmacotherapy; and regular follow-up. All these should be incorporated as a new standard into care of TB patients who smoke.

\section{CONCLUSIONS}

Raising awareness of the health risks of smoking in patients with TB as well as health providers and routine offer of tobacco-dependence treatment in established system of TB treatment in tobacco-free healthcare facilities may significantly contribute to 
increasing the abstinence success rate in patients with TB. Due to its low current availability but high potential impact, it is crucial to consider TDT in patients with TB as a topic for future research.

\section{REFERENCES}

1. World Health Organization, International Union Against Tuberculosis and Lung Disease. A WHO / The Union monograph on TB and tobacco control: joining efforts to control two related global epidemics. Geneva: World Health Organization; 2007. https://apps.who.int/iris/ bitstream/handle/10665/43812/9789241596220_eng. pdf? sequence $=1 \&$ isAllowed=y. Accessed November 12, 2019.

2. Dogar O, Bullen C, Novotny TE, Siddiqi K. Smoking cessation and respiratory disease in low-income and middleincome countries. Lancet Respir Med. 2013;1(5):e23-e24. doi:10.1016/S2213-2600(13)70123-1

3. Slama K, Chen-Yuan C, Enarson DA. Tobacco Cessation Interventions for Tuberculosis Patients: A Guide for LowIncome Countries. Paris, France: International Union Against Tuberculosis and Lung Disease; 2008.

4. Bates MN, Khalakdina A, Pai M, Chang L, Lessa F, Smith KR. Risk of tuberculosis from exposure to tobacco smoke: a systematic review and meta-analysis. Arch Intern Med. 2007;167(4):335-342. doi:10.1001/archinte.167.4.335

5. Wen CP, Chan TC, Chan HT, Tsai MK, Cheng TY, Tsai SP. The reduction of tuberculosis risks by smoking cessation. BMC Infect Dis. 2010;10:156. doi:10.1186/1471-2334-10-156

6. Jeyashree K, Kathirvel S, Shewade HD, Kaur H, Goel S. Smoking cessation interventions for pulmonary tuberculosis treatment outcomes. Cochrane Database Syst Rev. 2016;(1):CD011125. doi:10.1002/14651858.CD011125.pub2

7. European Network for Smoking and Tobacco Prevention. Guidelines for treating tobacco dependence. Brussels, Belgium: European Network for Smoking and Tobacco Prevention; 2018. http://elearning- ensp.eu/pluginfile. php/1052/mod_resource/content/2/guidelines_2018_ english.pdf. Accessed November 12, 2019.

8. Dogar O, Barua D, Boeckmann M, et al. The safety, effectiveness and cost-effectiveness of cytisine in achieving six-month continuous smoking abstinence in tuberculosis patients-protocol for a doubleblind, placebo-controlled randomized trial. Addiction. 2018;113(9):1716-1726. doi:10.1111/add.14242

9. The World Bank. World Bank Country and Lending Groups. https://datahelpdesk.worldbank.org/ knowledgebase/articles/906519. Published June, 2018. Accessed November 12, 2019.

10. Higgins J, Green S. Cochrane Handbook for Systematic Reviews of Interventions. Version 5.1.0. The Cochrane Collaboration; 2011. https://handbook-5-1.cochrane. org/. Accessed November 12, 2019.

11. Wells GA, Shea BJ, O'Connell D, et al. The Newcastle-
Ottawa Scale (NOS) for Assessing the Quality of Nonrandomized Studies in Meta-Analyses. http://www. ohri.ca/programs/clinical_epidemiology/oxford.asp. Accessed November 12, 2019.

12. Moher D, Liberati A, Tetzlaff J, Altman DG. Preferred reporting items for systematic reviews and metaanalyses: the PRISMA statement. BMJ. 2009;339:b2535. doi:10.1136/bmj.b2535

13. Aryanpur M, Hosseini M, Masjedi MR, et al. A randomized controlled trial of smoking cessation methods in patients newly-diagnosed with pulmonary tuberculosis. BMC Infect Dis. 2016;16:369. doi:10.1186/s12879-016-1727-4

14. Elsey H, Dogar O, Ahluwalia J, Siddiqi K. Predictors of cessation in smokers suspected of TB: Secondary analysis of data from a cluster randomized controlled trial. Drug Alcohol Depend. 2015;155:128-133. doi:10.1016/j.drugalcdep.2015.08.002

15. Goel S, Kathiresan J, Singh P, Singh RJ. Effect of a brief smoking cessation intervention on adult tobacco smokers with pulmonary tuberculosis: A cluster randomized controlled trial from North India. Indian J Public Health. 2017;61(Suppl 1):S47-S53. doi:10.4103/ijph.IJPH_265_17

16. Kumar SR, Pooranagangadevi N, Rajendran M, et al. Physician's advice on quitting smoking in HIV and TB patients in south India: a randomised clinical trial. Public Health Action. 2017;7(1):39-45. doi:10.5588/pha.16.0045

17. Louwagie GMC, Okuyemi KS, Ayo-Yusuf OA. Efficacy of brief motivational interviewing on smoking cessation at tuberculosis clinics in Tshwane, South Africa: a randomized controlled trial. Addiction. 2014;109(11):1942-1952. doi:10.1111/add.12671

18. Louwagie GMC, Ayo-Yusuf OA. Predictors of tobacco smoking abstinence among tuberculosis patients in South Africa. J Behav Med. 2015;38(3):472-482. doi:10.1007/s10865-015-9620-y

19. Sharma SK, Mohan A, Singh AD, et al. Impact of nicotine replacement therapy as an adjunct to anti-tuberculosis treatment and behaviour change counselling in newly diagnosed pulmonary tuberculosis patients: an open-label, randomised controlled trial. Sci Rep. 2018;8(1):8828. doi:10.1038/s41598-018-26990-5

20. Siddiqi K, Khan A, Ahmad M, et al. Action to stop smoking in suspected tuberculosis (ASSIST) in Pakistan: a cluster randomized, controlled trial. Ann Intern Med. 2013;158:667675. doi:10.7326/0003-4819-158-9-201305070-00006

21. Amara B, El Ghazi K, Rahimi H, Elbiaze M, Nejjari C, Chakib Benjelloun M. Attitudes et connaissances des pneumophtisiologues marocains vis-à-vis du tabagisme chez leurs patients tuberculeux [Attitudes and knowledge about smoking among Moroccan physicians looking after patients with tuberculosis]. Rev Mal Respir. 2008;25(5):569-575. doi:10.1016/s0761-8425(08)71614-0

22. Aryanpur M, Masjedi MR, Mortaz E, et al. Intention to 
Quit Smoking and Associated Factors in Smokers Newly Diagnosed with Pulmonary Tuberculosis. Tanaffos. 2016;15(1):17-24. PMID:27403174

23. Awaisu A, Mohamed MHN, Aziz NA, et al. Tobacco use prevalence, knowledge, and attitudes among newly diagnosed tuberculosis patients in Penang State and Wilayah Persekutuan Kuala Lumpur, Malaysia. Tob Induc Dis. 2010;8(January). doi:10.1186/1617-9625-8-3

24. Awaisu A, Mohamed MHN, Noordin NM, et al. The SCIDOTS Project: Evidence of benefits of an integrated tobacco cessation intervention in tuberculosis care on treatment outcomes. Subst Abuse Treat Prev Policy. 2011;6:26. doi:10.1186/1747-597X-6-26

25. Bam TS, Aditama TY, Chiang CY, Rubaeah R, Suhaemi A. Smoking cessation and smokefree environments for tuberculosis patients in Indonesia-a cohort study. BMC Public Health. 2015;15:604. doi:10.1186/s12889-015-1972-2

26. Boeckmann M, Warsi S, Noor M, et al. Health worker and patient views on implementation of smoking cessation in routine tuberculosis care. NPJ Prim Care Respir Med. 2019;29(1). doi:10.1038/s41533-019-0146-6

27. Brunet L, Pai M, Davids V, et al. High prevalence of smoking among patients with suspected tuberculosis in South Africa. Eur Respir J. 2011;38(1):139-146. doi:10.1183/09031936.00137710

28. Campbell IA, Chaudhary RD, Holdsworth GM, Lyne OD. Brief advice to tuberculosis patients in Nepal to stop smoking: a pilot study by the Britain Nepal Medical Trust. Int J Tuberc Lung Dis. 2014;18(12):1438-1442. doi:10.5588/ijtld.14.0358

29. Deepak KG, Daivadanam M, Pradeepkumar AS, Mini GK, Thankappan KR, Nichter M. Smokeless tobacco use among patients with tuberculosis in Karnataka: the need for cessation services. Natl Med J India. 2012;25(3):142145. PMID:22963290

30. El Sony A, Slama K, Salieh M, et al. Feasibility of brief tobacco cessation advice for tuberculosis patients: a study from Sudan. Int J Tuberc Lung Dis. 2007;11(2):150-155. PMID:17263284

31. Gupte HA, Zachariah R, Sagili KD, et al. Integration of tobacco cessation and tuberculosis management by NGOs in urban India: a mixed-methods study. Public Health Action. 2018;8(2): 50-58. doi:10.5588/pha.17.0085

32. Kanakia KP, Majella MG, Thekkur P, Ramaswamy G, Nair D, Chinnakali P. High Tobacco Use among Presumptive Tuberculosis Patients, South India: Time to Integrate Control of Two Epidemics. Osong Public Health Res Perspect. 2016;7(4):228-232. doi:10.1016/j.phrp.2016.06.001

33. Kaur J, Sachdeva KS, Modi B, et al. Promoting tobacco cessation by integrating 'brief advice' in tuberculosis control programme. WHO South East Asia J Public Health. 2013;2(1):28-33. doi:10.4103/2224-3151.115833

34. Lam C, Martinson N, Hepp L, et al. Prevalence of tobacco smoking in adults with tuberculosis in South
Africa. Int J Tuberc Lung Dis. 2013;17(10):1354-1357. doi:10.5588/ijtld.13.0016

35. Lin Y, Wang LX, Qiu LX, et al. A smoking cessation intervention among tuberculosis patients in rural China. Public Health Action. 2015;5(3):183-187. doi:10.5588/pha.15.0025

36. Louwagie GMC, Ayo-Yusuf OA. Tobacco use patterns in tuberculosis patients with high rates of human immunodeficiency virus co-infection in South Africa. BMC Public Health. 2013;13:1031. doi:10.1186/1471-2458-13-1031

37. Louwagie GMC, Morojele N, Siddiqi K, et al. Addressing tobacco smoking and drinking to improve TB treatment outcomes, in South Africa: a feasibility study of the ProLife program. Transl Behav Med. 2019;ibz100. doi:10.1093/tbm/ibz100

38. Mariappan VA, Sahu SK, Sarkar S, Kattimani S, Soundappan G. Smoked and smokeless tobacco use among pulmonary tuberculosis patients under RNTCP in urban Puducherry, India. Indian J Tuberc. 2016;63(3):158-166. doi:10.1016/j.ijtb.2016.08.004

39. Navya N, Jeyashree K, Madhukeshwar AK, et al. Are they there yet? Linkage of patients with tuberculosis to services for tobacco cessation and alcohol abuse - a mixed methods study from Karnataka, India. BMC Health Serv Res. 2019;19(1):90. doi:10.1186/s12913-019-3913-8

40. Ng N, Padmawati RS, Prabandari YS, Nichter M. Smoking behavior among former tuberculosis patients in Indonesia: intervention is needed. Int J Tuberc Lung Dis. 2008;12(5):567-572. PMID:18419894

41. Nichter M, Padmawati S, Ng N. Introducing smoking cessation to Indonesian males treated for tuberculosis: The challenges of low-moderate level smoking. Soc Sci Med. 2016;152:70-79. doi:10.1016/j.socscimed.2016.01.028

42. Pradeepkumar AS, Thankappan KR, Nichter M. Smoking among tuberculosis patients in Kerala, India: proactive cessation efforts are urgently needed. Int J Tuberc Lung Dis. 2008;12(10):1139-1145. PMID:18812043

43. Sereno AB, Soares EC, Lapa E Silva JR, et al. Feasibility study of a smoking cessation intervention in Directly Observed Therapy Short-Course tuberculosis treatment clinics in Rio de Janeiro, Brazil. Rev Panam Salud Publica. 2012;32(6):451-456. PMID:23370189

44. Shangase ZP, Tsoka-Gwegweni JM, Egbe CO. Barriers to Smoking Cessation Among Drug-Resistant Tuberculosis Patients in South Africa. Ann Glob Health. 2017;83(34):501-508. doi:10.1016/j.aogh.2017.05.007

45. Shin SS, Xiao D, Cao M, et al. Patient and doctor perspectives on incorporating smoking cessation into tuberculosis care in Beijing, China. Int J Tuberc Lung Dis. 2012;16(1):126-131. doi:10.5588/ijtld.11.0044

46. Siddiquea BN, Islam MA, Bam TS, et al. High quit rate among smokers with tuberculosis in a modified smoking cessation programme in Dhaka, Bangladesh. Public Health Action. 2013;3(3):243-246. doi:10.5588/pha.13.0051 
47. Tsai SL, Lai CL, Chi MC, Chen MY, Chen MY. Cigarette smoking and health-promoting behaviours among tuberculosis patients in rural areas. J Clin Nurs. 2016;25(17-18):2511-2519. doi:10.1111/jocn.13289

48. Warsi S, Elsey H, Boeckmann M, et al. Using behaviour change theory to train health workers on tobacco cessation support for tuberculosis patients: a mixed-methods study in Bangladesh, Nepal and Pakistan. BMC Health Serv Res. 2019;19(1):71. doi:10.1186/s12913-019-3909-4

49. Bissell K, Fraser T, Chiang CY, Enarson DA. Smoking Cessation and Smokefree Environments for Tuberculosis Patients. Paris, France: International Union against Tuberculosis and Lung Disease; 2010. https://www. theunion.org/what-we-do/publications/technical/english/ pub_smokingcessation_eng.pdf. Accessed November 12, 2019.

50. World Health Organization. MPOWER: A Policy Package To Reverse The Tobacco Epidemic. https://www.who.int/ tobacco/mpower/mpower_english.pdf. Published 2008. Accessed November 12, 2019.
CONFLICTS OF INTEREST

The authors have each completed and submitted an ICMJE form for disclosure of potential conflicts of interest. The authors declare that they have no competing interests, financial or otherwise, related to the current work. K. Zvolska, A. Pankova, I. Nohavova, R. Huque, H. Elsey, M. Boeckmann and A. Sheikh report grants from European Union's Horizon 2020 research and innovation programme, during the conduct of the study. K. Siddiqi reports grants from Pfizer and from European Union's Horizon 2020 research and innovation programme, outside the submitted work. E. Kralikova reports funding from Pfizer and grants from European Union's Horizon 2020 research and innovation programme, during the conduct of the study.

\section{FUNDING}

This work was supported by the European Union's Horizon 2020 Research and Innovation programme under Grant Agreement No 680995 and Project PROGRES 025/LF1 of the Charles University in Prague. This publication reflects only the authors' views. The European Commission (EC) is not responsible for any use that may be made of the information it contains. The funding agency had no role in designing or conducting the study, or in preparing this manuscript. The EC is not responsible for the content of this article.

\section{AUTHORS' CONTRIBUTIONS}

$\mathrm{KZ}, \mathrm{AP}$ and EK substantially contributed to conception and design, acquisition of data, and analysis. IN, RH, HE, AS and KS helped to interpret data. $K Z, A P, E K, I N, R H, H E, A S, M B$ and $K S$ revised the article critically for intellectual content, and finally approved the version for publication.

PROVENANCE AND PEER REVIEW

Not commissioned; externally peer reviewed. 